\title{
A ASEMBLEA DAS PROVINCIAS GALEGAS DE 1922, O MODELO MANCOMUNALISTA E A AUTONOMÍA INTEGRAL DE GALICIA
}

\author{
Por \\ BALDOMERO CORES TRASMONTE
}

\section{O DEBATE DAS MANCOMUNIDADES E A EXPANSIÓN EN GALICIA DO MANCOMUNALISMO PROVINCIAL}

\section{A acomodación do rexionalismo e o particularismo catalán}

O modelo de compatibilización da provincia e das deputacións provinciais con modelos de organización rexional concretouse nunha aspiración á implantación dunha Mancomunidade provincial, semellante á establecida en Cataluña ó abeiro do Real Decreto do 18 de decembro de 1913, do que Xosé Canalejas foi animador e teimudo propulsor. Unha das saídas posibles para resolve-lo conflicto creado polos particularismos rexionais, sen perda do que para os defensores do sistema liberal significaba a provincia, era atopar fórmulas que, aceptando básicamente aquela, puideran, ó mesmo tempo, respecta-las condicións da personalidade propia de comunidades con conciencia da súa vitalidade política ou administrativa. Como tóda-las fórmulas intermedias, tiña adversarios por un lado e por outro, de maneira que non era aceptada nin polos liberais máis radicais, como Uxío Montero Ríos, nin polos rexionalistas máis polarizados. Como tóda-las fórmulas de transixencia, polo tanto, estaba a mercede da forza e dos pulos que en cada momento tiveran os seus enimigos.

"CUADERNOS DE ESTUdiOS GALLEGOS", Tomo XLIII, Fascículo 108, Santiago 1996. 
A Mancomunidade catalana, implantada por Real Decreto de 26 de marzo de 1914, tivo ó mesmo tempo efectos miméticos e efectos contrarios. Para moitos catalanistas non era máis que un punto de partida, unha base máis cara unha rexionalización definitiva da vida catalana. Para moitos defensores da unidade da pátria e do Estado unitario e altamente centralista, calquera concesión desta natureza era unha concesión cara a desmembración dunha unidade que custara séculos acadar. Técnicamente, a creación das mancomunidades significaba un esforzo de reducción da potencia posible dunha unidade rexional nunha acción puramente administrativa, tentando de organizá-lo modelo soamente «para fins exclusivamente administrativos, que sexan competencia das provincias».

As Mancomunidades provinciais, segundo os seus fins propios, podían ordenarse de acordo con dous posibles modelos organizativos. Por un lado, mediante a creación dunha mancomunidade xeral, aínda que limitada administrativamente, na que se desenvolvía a personalidade total dunha rexión histórica. Tal era o caso da Mancomunidade catalana, creada mediante o devandito Real Decreto de 1914. Por outro lado, a mancomunación sectorial, para fins específicos ou concretos, non ofrecía aspectos de tipo político, aínda que técnicamente tampouco era de fácil solución. A Confederación do Ebro e a mancomunidade de Aragón eran exemplo dista segunda. Tanto o Real Decreto de creación das mancomunidades provinciais, como a implantación concreta da Mancomunidade catalana en 1914, axudaron a crear un modelo de organización dunha institución parella en Galicia. Facilitaban a comprensión da Mancomunidade galega algúns feitos concretos, como o ambiente de tensión que se vivía en Galicia por mor dos aranceis de Cambó, o antigo líder catalanista vencellado tan fondamente ós de Irmandade da Fala, e o esforzo dalgúns intelectuais que, sobre todo mediante a aportación concreta de Luís Peña Novo, facían comprensible no ambiente galego a posible implantación da Mancomunidade galega.

O modelo das mancomunidades provinciais é unha fórmula histórica creada para dar canle ás arelas rexionais dentro do sistema establecido ó abeiro da Constitución de 1876. A recepción de correntes científicas sobre descentralización administrativa, facilitaba o intento de conserva-la provincia como o esquema básico dunha concesión de personalidade a novos organismos periféricos. Na práctica administrativa e política, o modelo das mancomunidades provinciais foi, en realidade, o modelo da 
Mancomunidade de Cataluña, por se-la única que se creou baixo este esquema organizativo desde o punto de vista territorial. Malia da súa presencia histórica, tan limitada no tempo, a súa experiencia servirá para instala-la provincia no seo da rexión, como un instrumento de relación entre os entes provinciais e os entes rexionais, en épocas en que non existe o desexo dunha instalación rexional axeitada. En que grao, a presencia da provincia no sistema político actual, como no de 1931, ten vencello con aquelas experiencias e algo que hai que tratar máis demoradamente, pero que deben recoñecerse, cando menos, os principios en que se inspiraron.

Despois da aprobación polo Congreso dos Deputados dun proxecto de lei de Mancomunidades provinciais, e dun tenso debate na Cámara alta, no que se manifestaron nidiamente as posicións sobre as súas posibilidades, por mor de circunstancias específicas, ás que non foi allea o asasinato de Canalejas, foi posto en vigor o modelo por medio do Real Decreto de 18 de decembro de 1913, publicado baixo a firma de Xosé Sánchez Guerra, despois dunha forte presión de Prat de la Riva e dos presidentes das Deputacións catalanas sobre Eduardo Dato, presidente do Consello de Ministros.

O sistema durou moi pouco tempo, uns dez anos, máis ou menos, pois foi suprimido polo Estatuto Provincial, aprobado por Real Decreto-Lei do 20 de marzo de 1925. Durante ise tempo, soamente foi posible a constitución da Mancomunidade de Cataluña, polo que, en realidade, a historia das Mancomunidades provinciais como órganos territoriais foi a historia concreta e específica da experiencia catalana. Implantada por Real Decreto de 26 de marzo de 1914, a súa disolución produciuse coa entrada en vigor do Estatuto Provincial, logo dunha situación transitoria destinada a transferencia dos servizos asumidos polo organismo supraprovincial.

Malia da concepción unitaria do Estado e da organización centralizada da vida administrativa, baixo a vixencia diste texto constitucional de 1876 ofreceronse exemplos destacados de autonomía rexional. A Constitución para Cuba e Puerto Rico é a primeira testemuña do réxime autonómico dentro do ordenamento xurídico español, niste caso de recoñecemento da personalidade dunha parte do territorio ultramarino e colonial. Con carácter intraterritorial, no ano 1913, formalmente baixo a capa dunha mancomunidade creada ó abeiro dunha concepción da descentralización administrativa, aprobouse o primeiro réxime suprapro-

"CUADERNOS DE ESTUDIOS GALLEGOS", Tomo XLIII, Fascículo 108, Santiago 1996. 
vincial, no que se tentaba de circunscribi-las arelas rexionais. Xa máis directamente, por Real Decreto do 18 de decembro de 1918, o Consello de Ministros creou unha Comisión extraparlamentaria, co fin de estudiala forma de establecemento do réxime de autonomía rexional e das facultades que poderían ser recoñecidas ós poderes rexionais, o que deu logo orixe a un texto parlamentario.

A creación do modelo foi o resultado dunha coincidencia de esforzos entre posicións ideolóxicas e forzas políticas contrapostas, interesadas nunha axeitada acomodación sistémica. Entre os centralistas irreductibles e os irreductibles periferistas cataláns interpuxeronse os defensores de tendencias descentralizadoras, orientadas a aceptar e a incorpora-lo catalanismo espontaneista na vida constitucional. Como dixo axeitadamente El Noroeste, o día 13 de maio de 1914, calificando o modelo como unha de cal e outra de area, «las aspiraciones de los catalanes son complacidas, siquiera condicionándolas con los escrúpulos de Don Eugenio Montero». Para a resolución do conflicto, os vixiantes do sistema establecido, dacordo coas novas tendencias de descentralización administrativa, cedían facultades e funcións administrativas a un novo ente supraprovincial, pero sempre dentro da superior autoridade política e da soberanía do Estado. Os periferistas burgueses cataláns, baixo o maxisterio de Prat de la Riva e de Cambó ou a transixencia de Pedro Corominas, deixaban de momento aspiracións, utopías e actos de rueiro, para axustarse ás liñas básicas do ordenamento xurídico-político vixente, non sen protesta doutras forzas, como destacaba polo seu contraste Francisco Maciá.

En certo modo, o debate, desde o ángulo dos fins e dos obxectivos non tiña unha fácil solución. Consideraban moitos, por un lado e mais polo outro, que non se resolvía o problema, xa que o único que se lle entregaba os catalanistas era unha cómoda plataforma de lanzamento, para acadar novas trincheiras institucionais, ou, pola contra, desde as liñas catalanistas estabase que o único que se conseguía era dete-lo desenvolvemento da ideoloxía a prol de mellores fórmulas de expresión da personalidade rexional, necesitada de organismos máis axeitados ás necesidades colectivas do pobo catalán. 


\section{Sobre a constitucionalidade e os efectos da lexislación sobre man- comunidades}

A posible inconstitucionalidade, primeiro do proxecto de Lei de Mancomunidades provinciais, e logo do Real Decreto de 18 de decembro de 1913, provocou opinións discrepantes entre xuristas e políticos. Os que aceptaban a compatibilidade das Mancomunidades provinciais coa Constitución de 1876, incluso citando precedentes legais e parlamentarios, insistían na esixencia de que subsistira a provincia no seo do organismo supraprovincial, como base do acordo de mancomunidade, sen que puidera valdeirarse no novo organismo a persoalidade individual dos entes provinciais.

Por medio dun procedemento dispositivo e facultativo, seguido logo nos procesos estatutarios de 1931 e de 1978, a intención manifesta da lexislación das Mancomunidades provinciais era a de abrir canles para que as provincias contíguas que o desexasen e o necesitasen puideran integrarse en entidades de carácter supraprovincial. A intención latente da lexislación, desde unha perspectiva histórica moi concreta, estaba orientada a resolve-lo conflicto catalán, agudizado nos derradeiros tempos. Iniciabase así a estratexia lexislativa de subsumi-los particularismos máis concretos en normas de ámbito xeral ou territorial, como se repetiu logo nos devanditos procesos estatutarios de 1931 e de 1978.

O sistema establecido sentía-se máis amparado contra das acusacións de debilidade e de claudicación ante as forzas catalanas, si se establecía unha norma de tipo xeral, á que puideran acollerse outras provincias ou rexións que o desexasen, na medida en que tóda-las entidades poderían da-los mesmos pasos. Na medida en que se obrigaba a unha entidade específica a aceptar un principio xeral e a dar pasos concretos previamente establecidos, laboriosos moitas veces, afirmabase así o principio de autoridade estatal como elemento de integración dos distintos aspectos na totalidade do sistema político. A intención latente, sen embargo, desde un punto de vista histórico moi concreto, estaba orientada a resolve-lo conflicto catalanista, agudizado nos derradeiros tempos. Non será a única vez que se utilice ista estratexia lexislativa, pola que os particularismos se subsuman en normas de ámbito xeral, pois así se aplicou, tamén, na Constitución de 1931 e na Constitución vixente de 1978. Baixo unha norma de ámbito xeral ou territorial, concretable logo en forma dispositiva, o sistema establecido sentíase amparado contra as acusacións de claudica- 
ción ante o catalanismo, como se oía decote nos medios políticos. $\mathrm{Na}$ medida en que se obligaba a unha entidade rexional a dar pasos concretos, laboriosos moitas veces, afirmabase o principio de autoridade estatal, elemento de integración da totalidade do sistema.

A Mancomunidade de Cataluña foi a mellor testemuña de que non era posible instituciona-la personalidade das rexións no estreito ámbito dunha descentralización administrativa de nivel provincial. O modelo da Mancomunidade catalana exerciu efectos contradictorios na implantación de mancomunidades noutros ámbitos do territorio do Estado. Por un lado, era moi difícil descoñece-los logros da Mancomunidade catalana en materia de cultura, sobre todo na afirmación da língua catalana como vencello fundamental de convivencia. Pero, por outro, non faltaban os desconfiados, que vían como o organismo provincial asentaba os alicerces dunha personalidade colectiva necesitada dunha forma política concreta. Ó final, non foron posibles nen o desenvolvemento da Mancomunidade catalana nen o nacemento doutras Mancomunidades provinciais, como, por exemplo, a de Galicia, aínda que soamente como punto de partida a prol dunha autonomía integral e política.

\section{As mancomunidades provinciais, empeño persoal de Canalejas}

A opinión favorable de Canalejas a un proxecto de Mancomunidades provinciais foi o resultado dun lento proceso de maduración ideolóxica. Despois de escoitar a moitas persoas da súa estima, logo de analiza-los pros e contras e de profundizar na complexidade do problema, sobre todo do problema catalán, o líder ferrolán chegou ó convencemento de que a creación das Mancomunidades provinciais podería contribuir a resolvela cuestión catalana. O líder ferrolán era unha persoa moi impresionable, pero, coñecedor da súa debilidade, sabía contrarresta-la consultando decote a uns e mai-los outros, ata que chegaba a formarse unha idea concreta do asunto que lle preocupaba.

Desde o seu propio partido liberal, no que tamén se atopaban os máis duros enimigos da idea, había xente que aconsellaba a Canalejas unha política de rescate dos ánimos de Cataluña, para reducir ou acabar coa custión catalana. Unha das opinións máis estimadas para o dirixente ferrolán era a do prestixioso mercantilista Xosé Roig y Bergadá, quen entrou en política e foi líder do partido liberal precisamente da man de Xosé Canalejas. A opinión de Roig era doblemente estimada polo pre- 
sidente do Consello, porque ofrecía a versión dun catalán versado na súa propia cultura e, sobre todo, no seu dereito, que, ó mesmo tempo, estaba interesado en que o partido liberal acadase a debida influencia en Cataluña, cousa na que estaba moi interesado Xosé Canalejas.

Outros bos coñecedores da realidade social, cultural e política de Cataluña aconsellaron no mesmo senso a Canalejas. Entre outros, un dos seus gobernadores civís, Manuel Portela Valladares, conta como falou co presidente do Consello sobre a necesidade de instaura-la Mancomunidades catalana, como una forma de resolve-lo problema catalán dun xeito pacífico, ó que o propio Canalejas calificou como acción sedante. Argumentaba Portela ante o presidente do Consello, contra opinións contrarias doutros epígonos do partido liberal, que a Mancomunidade podería impedir que nacera outra Solidariedade catalana, aínda máis dura e efectiva. Portela deixou caer ante o presidente que a creación da Mancomunidade era un medio efectivo para reincorporar a Cataluña na política do Estado. Parece que Canalejas non estivo moi explícito naquel xantar, pois escoitou ós vellos liberais que mantiñan a tese contraria, pero Portela decatouse de que a súa opinión estaba gañada e que soamente abondaba con esperar a que callase o fruto, como así sucediu pouco tempo despois.

Cando chegou ó convencemento das avantaxes das Mancomunidades provinciais como fórmula de artellamento das arelas rexionais en dispositivos de descentralización administrativa local, Canalejas tomou co máximo empeño persoal, a iniciativa e o impulso do proxecto. Poucas veces un home público abrazará con tantos pulos, contra vento e marea, unha peza lexislativa, interesado en que se convertira en lei e servira para ordena-la vida administrativa e política de España, xuntando a súa confianza política á confianza no proxecto que defendía.

Unha vez que estimou necesario o acto do recoñecemento da personalidade de Cataluña, aínda que pola vía indirecta da xeneralización das Mancomunidades provinciais; non tivo o menor reparo en recibir ós presidentes das súas Deputacións provinciais. Como explicou na sesión parlamentaria do 3 de xullo de 1912, no debate das Mancomunidades provinciais: «los hombres en quienes había depositado mi confianza, las personas ilustres a quienes había requerido para que constituyesen un partido liberal en Cataluña, me dijeron que prestaría el más grande de los 
servicios a mi Patria y a mi Rey si yo recibía a las Diputaciones catalanas, no en son de guerra, no en tono despectivo, no para engañarlas con promesas ilusorias que desvaneciera el tiempo, sino con la honradez y la sinceridad de un gobernante que quiere prestar el primero de los tributos debidos al Rey y a la Patria: el de la honradez en el cumplimiento de sus compromisos».

A recepción dos presidentes das catro Deputacións provinciais de Cataluña celebrouse en Madrid o día 8 de decembro de 1911. Falou primeiro Prat de la Riva, pronunciando un discurso no que subliñou que as Bases que presentaban naquel acto non era o programa de ningún partido político en concreto e que cada un deles, por separado, movidos por sano impulso patriótico, sacrificara parte dos seus ideais a prol da común solución que presentaban naquel acto. Calificou as Bases como unha fórmula incipiente de descentralización, pola delegación de funcións en materia de obras públicas, cultura e beneficencia, pero fixo un xogo de palabras co concepto, xa que «en realidad lo que se propone es devolver a cada centro, a cada entidad, las funciones que le son propias».

Na súa resposta, Canalejas non dubidou en recoñecer que existía un sentimento xeral de Cataluña, como se demostraba pola cantidade de telegramas que recibira no seu despacho. Pero, non será esta a última vez que o despacho de Canalejas se encha de telegramas. Na sesión do 3 de xullo de 1912 utilizará tamén como razón do seu argumento a manchea de telegramas recibidos, explicando «...como que el éxito superior, si hay éxito en esta política, está en que hoy, sobre la mesa de mi despacho, tengo no sé cuantos telegramas de Ateneos federales, de Ateneos republicanos, de Centros republicanos, de Corporaciones de toda especie, sumados a los telegramas del Sr. Sedó, a los telegramas de las fuerzas conservadoras de Cataluña; en suma, la expresión de un sentir general de todo el país».

O presidente do Consello aproveitou tan solemne ocasión para desfacela idea de que o partido liberal era un freo para as aspiracións de Cataluña. Falando quizais tanto ou máis para os líderes do seu partido que para os presentes, propuxo a busca dunha fórmula compatible co estado presente da nación e mantendo aquelas facultades da soberanía do Estado que son insustituibles e que non poden desvincularse, non tendo dificultades no restante. Para que as palabras non fóran vans, tantas veces utilizadas en actos deste tipo como fórmulas de evasión, o presidente propuxo, 
incluso, un calendario aproximado para o comezo de debate, o que era indicio máis que dabondo para que as súas palabras puideran ser valoradas co mesmo espíritu con que o líder ferrolán as pronunciaba.

Canalejas non descoñecía que dentro e fóra do seu partido, as diferencias eran demasiado profundas como para que non se contemplaran próximas batallas. Estaba seguro de que a lei era unha boa solución para resolvelo problema catalán, pois, aínda perdendo algo ámbalas dúas partes podían todos beneficiarse da estabilidade do sistema constitucional. Na sesión parlamentaria do 1 de xuño de 1912 dixo que era «un proyecto que he leído con la honrada convicción de que presto a mi país un servicio, con el firme convencimiento de que ese proyecto asegura la paz y evita conflictos».

O día 27 de xuño de 1912, os catalanistas membros da Comisión dictaminadora do proxecto de lei de Mancomunidades provinciais agasallaron cun banquete a Canalejas e a Antonio Barroso, o Ministro da Gobernación que firmou e deu lectura ó proxecto, para festexa-lo comezo do debate do proxecto no Congreso dos Deputados. Cando os brindis, o Conde de Romanones, presidente do Congreso, tamén invitado, pronunciou unhas enigmáticas palabras, tan enigmáticas como el mesmo, que dicían así: «Brindo por la brillantez y la solemnidad que ha de tener el debate», palabras que daban que desconfiar e que revelaban, unha vez máis, o carácter intrigante do aristócrata. En cambio, Xosé Canalejas foi rotundo, claro e directo: «Yo brindo por llevar en la segunda quincena de noviembre a la sanción del Rey la ley de Mancomunidades, porque ello será indicio de que vive y existe el partido liberal». Na sesión do primeiro de xullo de 1912, na súa intervención parlamentaria, insistirá na súa leal e inconmovible promesa: «El Gobierno desea, vivamente desea, tener el honor de suscribir la promulgación de esa ley en el plazo más breve que esté a su alcance. Otra cosa no se le puede pedir a un Gobierno, otra declaración no se le puede pedir a un hombre sin agraviar su confianza». Mal sabía o político ferrolán que o seu desexo non se cumpliría endexamais...

Despois de moitas voltas, no medio dunha expectativa xeral e de manifestacións contrarias entre os prohomes do partido liberal, o proxecto de lei de Mancomunidades provinciais tomou estado parlamentario. Que o camiño no seo do Congreso non era tan simple, ben o sabía Canalejas 
soamente con que lera os xornais e escoitase o balbordo dos enimigos do proxecto. Entre recelos, desconfianzas, medos e contratempos inesperados, o proxecto de lei foi avanzando algúns pasos.

Cando o Ministro da Gobernación, Antonio Barroso, fixo a primeira lectura preceptiva do proxecto de lei, había moita xente que non daba creto o que vía e escoitaba. As declaracións dos epígonos do partido liberal non deixaban xa dúbida sobre a súa actitude hostil ó proxecto. Máis ou menos abertamente, Moret, Montero Ríos, o Conde de Romanones, figuras máximas do partido liberal, deixaban cae-las súas declaracións en senso contrario ó proxecto. O 10 de xuño de 1912, xa nomeada a Comisión, Moret anuncioulle ós seus membros o seu sentimento por ter que combate-lo proxecto de lei.

Compoñe-la Comisión dictaminadora do proxecto foi unha das dificultades máis grandes coas que se atopou Canalejas durante o iter parlamentario do proxecto de lei de Mancomunidades provinciais. Despois de moitas consultas e invitacións, logrou que formasen parte dela, sendo designados o día 5 de xuño de 1912, Trinitario Ruíz Valarino, como presidente, e home da absoluta confianza de Canalejas; Xosé Manuel Pedregal, que aseguraba o exame desde a perspectiva económica; Alfonso Sala, equilibrista ideolóxico, interesado no catalanismo, foi nomeado secretario, e Pedro Corominas e Francisco Cambó, procedentes de dúas ramas distintas, pero coincidentes no proxecto, do catalanismo. Completaban a Comisión dictaminadora Anxel Alvarez de Mendoza e Xosé Guillén Sol.

Era idea de Canalejas que estivera composta por tóda-las forzas políticas existentes no Parlamento, pero non foi posible. Vázquez de Mella disculpouse dicindo que os rexionalistas xa estaban representados. Maura adoptou unha actitude pasiva desde o principio, porque sentíase despoxado dun modelo organizativo que coidaba lle pertencía, porque fóra no debate do seu proxecto de Administración local cando se empezou a falar das mancomunidades provinciais. Incluso as forzas políticas que non ían votar en contra, e que transixían cando menos co proxecto, non estaban dispostas a participar activamente na elaboración interna da lei. Canalejas sinteuse na obriga de explicar durante o debate do proxecto de lei a orixe dos membros da Comisión, sobre todo dos catalanistas, obxecto de discusión: «El Sr. Corominas, como el Sr. Cambó, fueron requeridos por mí para formar parte de la Comisión, y yo tengo bastante conciencia de lo que suponía el llamar a dos Sres. Diputados, dignísimos representantes

"CUADERNOS DE ESTUdiOS GALLEGOS", Tomo XLIII, Fascículo 108, Santiago 1996. 
de dos elementos de tanta importancia en Cataluña, para el objeto que acabo de indicar». A vista da obxectividade con que, dentro sempre do seu obxectivo ideolóxico, mantiveron Cambó e Corominas, a Comisión encargoulle-la elaboración formal do articulado, unha vez que chegaron a unha coincidencia nos aspectos fundamentais.

Tamén Cambó, na sesión do 3 de xullo, explicou os motivos polos que aceptou a invitación do presidente do Consello de Ministros. Coincide con Canalejas en que era necesario participar na Comisión, destacando o ambiente que se viviu nela: «No tengo más que palabras de elogio que dirigir a todos los individuos que de ella forman parte, y al Sr. presidente del Consejo de Ministros y al Sr. Ministro de la Gobernación que a nuestros trabajos colaboraron». Explica que cando se demandaban garantías para o Estado, «para que jamás pudiesen quebrantarse principios que todos hemos de defender incólumes, éramos los representantes catalanes los que ofrecíamos primero una solución, los que primero dictábamos esa garantía». Explica que «ninguna de las aspiraciones legítimas defendidas por nosotros encontró en ellos una resistencia sistemática».

\section{A elaboración do dictame e a actividade de Canajelas}

Canalejas participou moi activamente na elaboración do dictame. Malia das cousas que abrumaban ó presidente do Consello de Ministros, non tivo o menor reparo en xuntarse coa Comisión parlamentaria encargada da elaboración do dictame, nunha lección de humildade, e de crencia no parlamento, que poucas veces se da na vida política española. Un presidente dun Consello de Ministros, nada ocioso, superlaborioso como Canalejas, coa cabeza chea de proxectos, daba unha lección de aprecio á institución parlamentaria, acudindo voluntariamente, sin necesidade de especial chamamento, a unha Comisión, que practicamente actuaba naquel momento como unha ponencia. No seu longo discurso do 1 de xullo de 1912 explicou este feito: «La principal responsabilidad de ese dictamen es mía, como todos sabéis y conocen los individuos de la Comisión, porque mis dignos y queridos compañeros de la mayoría, como los señores Diputados por Cataluña, saben que he asistido a todas las deliberaciones, y que hasta el último inciso, si no lo escribí, me fue consultado, y que todo lo que hay ahí, con todas esas enormidades que se me denuncian, todo es fundamentalmente obra suya y obra mía».

"CUADERNOS DE ESTUDIOS GALLEGOS", Tomo XLIII, Fascículo 108, Santiago 1996. 
A Comisión empezou por debater primeiro unha emenda presentada polas catro Deputacións provinciais de Cataluña. A Canalejas pareciulle ben que antes de entrar no articulado, se puxera a votación da emenda das catro Deputacións catalanas. O 27 de maio de 1912, unha vez coñecido o proxecto pola primeira lectura de Barroso, xuntaronse os presidentes das catro deputacións catalanas. Aceptando o esquelete do proxecto, pretendían os presidentes ensancha-las competencias mediante delegacións do Estado, entre as que citaban as de obras públicas, montes, catastro, compensacións fiscais, etc. Consideraban que o maior defecto estaba na esixencia dunha nova lei para constituí-las mancomunidades, así como a facilidade para aproba-las existentes. Aprobaronse os seis primeiros artigos sen moito debate, pero o setimo, como non estaba Canalejas, quedou pendente para a sesión 14 de xuño.

A Comisión abriu, incluso, un prazo informativo, para que as persoas e grupos que o estimaran oportuno puideran comparecer a expoñe-los seus puntos de vista. Acudiron representacións dos enxeñeiros agrícolas e do Corpo de Telégrafos e un sevillano pidiu, incluso, sancións para as provincias que non quixeran mancomunarse. Unha nova desconfianza parecía xordir no avance do proxecto. Despois de elaborado o dictame, Canalejas quixo leva-lo de novo ó Consello de Ministros. O Consello deixouno pendente de exame, ata que Canalejas consultara con certas persoalidades. A entrevista co Conde de Romanones, sutilmente, non manifestamente hostil, ó proxecto, fixo temer de novo polo seu destino. Cando os xornalistas interrogaron ó presidente do Consello de Ministros, este respostoulle visiblemente cabreado: «¿Pero que líos son esos de las mancomunidades? El Gobierno sostiene el proyecto.jNo he visto nunca tanto embrollo como ahora!», dixo o 18 de xuño de 1912.

O 28 de xuño de 1912 puido dar comenzo o debate do dictame do proxecto de lei de Mancomunidades provinciais. O debate tivo moitos atrancos. A loita interna, abertamente expresada polas duras palabras que se cruzaron de seguido entre Segismundo Moret e Xosé Canalejas, revelaba a posibilidade de que nalgún momento o presidente do Consello podería quedarse sen os votos precisos para aproba-lo proxecto de lei. $\mathrm{Na}$ sesión do 1 de xullo de 1912, Francos Rodríguez, Merino e outros presentaron unha cuestión incidental, pregando ó Congreso unha declaración de que mantiña a súa confianza en Canalejas. O Conde de Sagasta 
pronunciouse a favor. Os demais abstiveronse, alegando Cambó e Vázquez de Mella que non tiña relación co debate. Foi aprobada por 171, sin que houbera votos en contra.

Resolta favorablemente a cuestión incidental, Rodrigo Soriano, Corominas e outros presentaron outra para pregar que se puxera inmediatamente a discusión o proxecto. Canalejas respostou: «Yo dije además, y no en una sola circunstancia y a una sola persona, sino a cuantos me quisieron oir, que a este proyecto asociaba mi vida ministerial, que este proyecto sería realizado y traducido en ley». E afirmou rotundo: «El Gobierno está completa y absolutamente resuelto a que prosiga este debate, no sólo para el fin respetabilísimo de escuchar las opiniones de los Sres. Diputados a quienes representa el Sr. Corominas, sino para llegar lo más rápidamente posible al término de éste debate». Ante as palabras de Canalejas, Corominas retirou a súa proposición. E o debate proseguiu, e os tiros soaban de todas partes, e Canalejas non abandonaba o seu intento, aquel empeño persoal no que se embarcou coa ilusión de resolve-lo problema catalán; e non esquencía que, parapetado detrás da presidencia do Senado, o pior enimigo do proxecto, o ilustre compostelano, Uxío Montero Ríos, esperaba a chegada de tan dooroso e perseguido proxecto de lei...

\section{Montero Ríos e o til dos seus ideais xacobinos}

Montero Rios foi un dos máis teimudos e constantes enimigos do proxecto de lei das Mancomunidades provinciais. Desde unha longa instalación no Estado unitario e centralizado, de inspiración xacobina, o notable compostelano amosou sempre unha gran hostilidade contra os excesos do catalanismo. Cando en 1905 foi presidente do Consello de Ministros, tocoulle padece-lo incidente do Cut cut, do que se derivaría a lei de Xurisdiccións, ante a que o vello santiagués preferiu dimitir que darlle o seu recoñecemento persoal, como fixo logo Segismundo Moret. No ano 1909, discutindo o proxecto de lei de Administración local cos rexionalistas cataláns afirmou rotundo que «no hay otra nacionalidad, no puede haberla, porque ello sería incompatible con la unidad constitucional de la España moderna».

Sin cambiar no aspecto teórico o seu concepto de Estado, nin alteralo seu pensamento sobre a cuestión catalana, fixo desde o primeiro momento unha total e absoluta oposición ó proxecto de lei de Mancomuni-

"CUADERNOS DE ESTUDIOS GALLEGOS", Tomo XLIII, Fascículo 108, Santiago 1996. 
dades provinciais. O 10 de xuño de 1913 deixou nidiamente expresado o seu vello pensamento: «Yo me opongo a que se aprueben las mancomunidades. ¿Por qué? Porque las creo lesivas contra la unidad de la patria». Instalado en tales seguridades conceptuais, o vello compostelano desenvainou a espada dos seus trucos e de tóda-las fórmulas de obstruccionismo parlamentario, nas que sempre foi un mestre, contra o proxecto querido de Canalejas.

Montero Ríos ostentaba a presidencia do Senado cando o proxecto chegou do Congreso á Camara alta. Cómo podería salvar tan difícil valo Canalejas, cando o proxecto chegara ó Senado, é cousa que quedou sin resolver, debido ó fatal pasamento do líder ferrolán. Pero, o certo é que, Montero Ríos, en defensa do dogma da unidade inconmovible da patria, utilizou todo tipo de artimañas e trucos parlamentarios. Fórmulas dilatorias, sombras e ambiguedades sobre prazos e designación de órganos, abandono simbólico e efectista da presidencia, para ocupar un escano, foron algunhas das tácticas empregadas polo político compostelano no seu intento de acabar co proxecto de Mancomunidades provinciais. Mestre nas artes parlamentarias, nas boas e nas malas, enriqueciu a historia do obstruccionismo con todo tipo de trucos e de medios de oposición a un proxecto que estimaba lesivo para a patria.

Como presidente do Senado, Montero Ríos aproveitou tóda-las súas potestades dispoñibles para obstaculiza-lo avance na tramitación do proxecto de lei. Dilatou na medida das súas posibilidades o cumprimento do trámite da primeira lectura. Retrasou despois a designación da Comisión dictaminadora do proxecto. Chegou un momento que non era posible saber en que sesión había de incluirse, como se distribuirían as quendas de intervención no debate e, incluso, despois de anunciarse o seu comezo para unha data foi logo incluído na orde do día doutra posterior, o que produxo máis dun susto ós que miraban con expectación o desenvolvemento do drama parlamentario.

Iniciado o debate, dun xeito simbólico e sempre efectista, na sesión do 4 de xuño de 1913, o notable compostelano abandonou a presidencia e pasou a ocupar un escano, pero non chegou a usar da palabra. Moito máis cauto que Segismundo Moret, as escisións no seo do partido liberal non se coñecían exactamente polas súas palabras. Pero, quen quixera ler nos xestos, nos ademáns, nas actitudes do patriarca compostelano, podía sa- 
ber cales eran os seus pensamentos e a emoción con que se estaba a opoñer a unha causa que, por moi equivocado que estivera, estimaba lesiva para a patria, por utiliza-la súa mesma linguaxe.

Montero Ríos fixo unhas declaracións públicas para mover ó presidente do Consello de Ministros a que deixara en liberdade «a todos los senadores liberales para discutir y votar con arreglo a sus convicciones y sentimientos», aclarando que debía face-lo «sin que el Gobierno trate de ejercer sobre ellos presión para que se aprobase». Non era nova a técnica, para situarse contra unha peza lexislativa sin racha-lo partido, porque xa, polo menos, se aplicara con motivo da lei de Xurisdiccións, unha lei contra que estivo Montero Ríos cos mesmos pulos que contra a de Mancomunidades, en defensa da xurisdición civil. Na sesión do día 9 de xuño, o Conde de Romanones, como presidente do Consello, aceptou que os deputados votaran libremente, «para mantener la unidad de la mayoría». Con esta victoria o líder santiagués asegurabase o voto de moitos membros do partido liberal que, asediados polo Goberno, podían manifestarse a prol do proxecto de Mancomunidades. Estaba seguro que deste xeito se aseguraba fraccións do partido liberal disconformes co proxecto e que, sin ser monteristas, tamén compartían o mesmo dogma da unidade da patria.

Montero Ríos non asistiu á sesión do día 6 de xuño, polo que esparciuse decote o rumor de que demitira como presidente do Senado, si ben o político santiagués non fixo ningunha manifestación ó respecto. O Ministro de Obras Públicas, López Muñoz, puido impedir que os vicepresidentes Portuondo e Roda, reconsiderasen o seu intento de demitir tamén, en solidariedade co presidente, o que xa indicaba que o feito da demisión era moito máis que un simple rumor. Unha cadea de demisións, como a do fiscal do Tribunal Supremo, Comisario Xeral de Abastos e outros tamén dispostos a demitir, indicaban os pulos con que o notable compostelano tomara $\mathrm{o}$ asunto das Mancomunidades.

Xa próximo o momento da votación, Montero Ríos aínda quixo gañar unha nova batalla en tan azaroso debate. Na sesión do día 7 de xuño, Montero Ríos pide a retirada do artigo primeiro do proxecto, ofrecendo unha transacción sobre o resto do texto. De accede-lo Goberno a que se retirase tal artigo, significaba deixar sin cabeza practicamente o proxecto de lei. A pretensión de Montero non tivo éxito, polo que se seguiu co debate e logo foi obxecto de votación.

"CUADERNOS DE ESTUdIOS GALLEGOS", Tomo XLIII, Fascículo 108, Santiago 1996. 
O momento da votación foi especialmente dramático. O lío era fenomenal. O presidente en funcións non daba controlado a situación, polo que tivo que erguerse Montero Ríos para aquieta-los ánimos, ante o que o presidente en funcións aclarou que se sometía á súa autoridade por ser aínda presidente da Cámara. Algún xornal describiu a situación dicindo que o ambiente na Cámara alta, normalmente aburrida, era de resolta loita. No medio de tal barullo, a votación do artigo primeiro deu un resultado de 111 votos a favor e 97 en contra, o que foi considerado como un gran éxito para Montero Ríos, xa que a diferencia de 14 votos indicaba a forza que tiña no seu propio partido.

Acompañaron a Montero Ríos cos seus votos, os senadores compostelanos Cleto Troncoso, Xosé Casares Gil e Xosé Rodríguez Carracido. Que Cleto Troncoso e Xosé Casares Gil votasen con vello ex presidente era moi normal, porque eran monteristas ata a cerna e debían os seus escanos ó seu veciño natal. En cambio, naquel momento, producíase unha curioso coincidencia entre Montero Ríos e Carracido, distanciados desde as famosas obras da Universidade compostelana. Esquecido do seu rexionalismo galego, Carracido estaba xa algo máis próximo a Montero Ríos en materia da unidade da patria, si ben de vivir Canalejas a súa capacidade de votar libremente non lle sería tan fácil como naquel momento. Manuel García Prieto, xenro de Montero Ríos, votou a prol do proxecto, á vista de que era Ministro no Goberno de Canalejas cando se presentou o proxecto de lei no Congreso dos Deputados.

A crise de goberno, a suspensión das sesións, todo foi causa de que o proxecto de Mancomunidades non pasara daquel artigo primeiro. O político galego, avaliando a súa demisión e a crise de goberno, dixo rotundo: «Yo no tengo por qué rectificar. Mi convicción es tan firme en esto como mi resolución. Ni deseo ni espero nada. Este es un puesto de honor, y por ninguna consideración faltaré a mi deber. Y mi deber es no rectificar ni una tilde de mis ideales ni de mis palabras». E non rectificou, pero tampouco alcanzou a ver como o réxime de Mancomunidades será aprobado por Real Decreto. O iter parlamentario do proxecto de Lei de Mancomunidades provinciais, presentado no Congreso dos Deputados o 4 de maio de 1912, é un sobre os que máis se practicou o obstruccionismo parlamentario. Soamente a capacidade resolutoria de Xosé Canalejas, instigado por Cambó e demais catalanistas, podía levar adiante un proxecto que contaba coa retesía dos centralistas e cunha forte oposición dentro do seu propio partido liberal.

"CUADERNOS DE ESTUDIOS GALLEGOS", Tomo XLIII, Fascículo 108, Santiago 1996. 
Canalejas foi acusado de ser esclavo de Cataluña e de Francisco Cambó. Na sesión do 1 de xullo dicía: «Yo no he presentado este proyecto con miras exclusivas a Cataluña; yo lo he presentado respondiendo a la presión, a la coacción de unos cuantos Diputados catalanes. Aquí tengo las firmas de los representantes de todas las Diputaciones provinciales de España. Todos proclamaban, todos pedían el proyecto de mancomunidades». Na Asamblea de Deputacións provinciais de Sevilla, en efecto, as Deputacións coincidiron en pedi-la creación de Mancomunidades provinciais, pero logo, unha vez instaurada a Lei de Mancomunidades todo quedou en intentos e a única que chegou a súa implantación real foi a de Cataluña. Na sesión do 3 de xullo, insistía en que non estaba sometido ás suxestións de Cambó.

As loitas internas do partido liberal manifestabanse por calquera cousa, pois eran loitas persoais, orientadas a facerse coas rendas do partido. Despois da morte de Sagasta, o partido dividiuse en seguidores de Segismundo Moret e seguidores de Uxío Montero Ríos e entre Moret e Canalejas. As Mancomunidades provinciais era, precisamente, un dos puntos críticos no que discrepaban os liberais das distintas tendencias. Durante o debate produciuse unha cuestión de confianza, de tipo incidental, provocada para asegurarse a maioría Canalejas. Chegou un momento en que no partido liberal non se sabía ben quen estaba a un lado ou a outro. Superou ista con creces, polo que sigueu intensificando o seu esforzo.

Había cousas, sen embargo, nas que as familias liberais non estaban dispostas a transixir. Unha das máis discutidas era precisamente a do modelo de Mancomunidades provinciais. Canalejas, na sesión do 3 de xullo, dixo: «El partido liberal no puede ser el conglomerado de fuerzas y de personalidades contradictorias que anulen mi acción, porque tengo que responder ante mi Patria y ante mi Rey, porque tengo que responder ante vosotros, que habéis depositado en mí vuestra confianza,vuestro honor político, y no puedo realizar esta política con distingos, con cortapisas, con vacilaciones en la mayoría».

Pedro Corominas e Francisco Cambó ofreceron unha perspectiva da situación catalana e do problema rexionalista en Cataluña. As súas manifestacións son moi importantes para coñece-lo alcance e as intencións do proxecto de lei de mancomunidades provinciais. Aínda que o proxecto estaba formulado con carácter xeral, en realidade o debate centrouse en Cataluña, como se unha lei xeral tivera como único ou principal obxecto 
a solución do problema rexionalista de Cataluña. Cambó tentou de explica-la nova situación política, con cambio de tácticas con respecto a política a seguir por Cataluña nas súas reivindicacións. Na sesión do 3 de xullo, Cambó aclarou a situación: «Ha sido característica de la actuación política catalana, todos los sabéis, la protesta, la oposición a todos los Gobiernos; nuestra significación, la significación de la minoría regionalista, es hoy por hoy de respeto igual, de consideración igual, de colaboración a todos los Gobiernos que puedan dar una satisfacción a nuestro país».

\section{A aprobación por decreto das mancomunidades provinciais}

Frustrado o intento de aprobar no parlamento español o proxecto de lei de Mancomunidades provinciais, o día 18 de decembro de 1913 foi aprobado por Real Decreto, baixo a firma de Xosé Sánchez Guerra. Dous ferrolanos de nacemento participaban no iter azaroso e balbordante de creación de Mancomunidades provinciais. Iniciado por Canalejas, como proxecto de lei, rematou por ser un decreto, sendo presidente do Consello de Ministros Eduardo Dato. Iniciado por un goberno liberal, moi dividido, foi aprobado por un goberno conservador, moito máis compacto, pero tamén dividido entre mauristas e idóneos, que se aseguraba a súa ratificación polas Cámaras lexislativas. Que fora un goberno conservador o que promulgase o decreto non tiña nada de particular. Pero, era Dato un conservador máis conservador que Maura, xa que non seguía aquelo da revolución desde arriba nin procuraba a democratización do partido, como facía Canalejas no partido liberal.

O 22 de outubro de 1913, Cataluña saíu ás rúas, para reclama-la creación das Mancomunidades provinciais. Días antes de que se celebrara a Asamblea de Diputacións provinciais de Cataluña, unha manifestación impresionante cubriu tóda-las rúas de Barcelona. Unha soa pancarta, expresión da unidade, dicía sinxelamente: «Cataluña y las Mancomunidades», porque querían que se levara a cabo a idea da extensión da fórmula a outras, de xeito que o seu esforzo fora amparado por outros pobos. Os comercios de Cataluña fecharon, co cartel: «Cerrado como adhesión a la Asamblea de las Mancomunidades». Dicíase que aquelo lembraba os actos de fervor de cando a Solidariedade catalana.

No Salón de San Jordi, baixo a presidencia dos catro presidentes das Deputacións provinciais de Cataluña, estaban 91 senadores e deputados e 
un público desbordante. Prat de la Riva no seu discurso calmou a xente: «No será culpa nuestra si no se consigue nada; pero habremos hecho lo que es nuestro deber». Despois da crise de goberno, producida sobre todo pola división do partido liberal, entre monteristas e contramonteristas, entrou Eduardo Dato de presidente do Consello de Ministros, e nomeou a Xosé Sánchez Guerra ministro da Gobernación. Os representantes de Cataluña en Cortes pedironlle unha cita, «a fín de notificarle los acuerdos adoptados por la Asamblea de las Diputaciones catalanas» e coñecer, ó mesmo tempo, o pensamento do novo Goberno.

Con eleccións á vista, os pulos acadados polo catalanismo, Eduardo Dato e Sánchez Guerra comprometeronse a levar adiante a creación das Mancomunidades provinciais. Dada a urxencia do asunto, xa non esperaron a reunión das Cortes, e por eso se aprobou por Decreto. Sánchez Guerra dixo: «Nadie dejará de reconocer que, conforme a las circunstancias, nos hemos colocado en el punto en que debíamos proceder, sin invadir terreno en los límites y puntos en que las Cortes habían de decir la última palabra».

\section{A CODIFICACIÓN DO MANCOMUNALISMO NO PENSAMENTO GALEGO}

\section{A aportación doctrinal e a doctrina política e administrativa}

A publicación do Real Decreto de Mancomunidades provinciais no ano 1913 non excitou demasiada producción científica fóra de Cataluña. O gran debate entre rexionalistas e centralistas producíase, sobre todo, na area política, non podendo a ciencia xurídica sustraerse á inevitable contaminación ideolóxica. Na práctica política, os desexos da oposición nacionalista, por exemplo, orientabanse xa daquela a novas aspiracións, á procura de novos rumbos a prol do autonomismo integral. Na realidade administrativa, a Asemblea de Concellos e Deputacións provinciais de 1922, fixo pensar na posibilidade de crear unha organización supraprovincial, pero non foi máis aló dunha simple coxuntura.

A producción doctrinal sobre o municipalismo e o rexionalismo tiña xa certa tradición en España. Gumersindo de Azcárate abriu unha brecha importante no macizo concepto centralista, pero será, sobre todo, o seu discípulo Adolfo Losada quen depure histórica e conceptualmente as novas 
estructuras e propostas do que se empezou a chamar Administración local. Formado como Azcárate, Canalejas e outros descentralizadores ó abeiro da Institución Libre de Enseñanza, o mestre de investigadores da socioloxía e politólogo eminente, foi algo así como un oráculo da ciencia xurídica en España. Evolución legislativa del Régimen Local en España, 1812-1909, publicado en 1910, e El régimen municipal de la ciudad moderna, publicado en 1916 e logo reeditado catro veces ata 1936, aseguraban o seu maxisterio científico en materia de réxime local, como quería Azcárate, ou de Administración local, como logo se popularizou.

Adolfo Posada era consultado decote por Segismundo Moret e por Xosé Canalejas, cando non polo mesmo Antonio Maura, en materia de Administración local. Como tantos outros, científicos e non científicos, Posada sentía moi vivo o sortilexio carismático de Canalejas, a que consideraba un dos representantes da política liberal en España de formación máis moderna, de orientación social máis definida e de espíritu máis aberto. Cando en 1912, Canalejas lle encargou a preparación dunhas Bases da Administración local, di o mestre asturiano que «las redacté inspirándome, según sus instrucciones y las del ministro de la Gobernación, Sr. Barroso, en el proyecto de Maura, aprobado casi totalmente por las Cortes conservadoras, pero recogiendo ciertos puntos de vista sostenidos en dichas Cortes por las representaciones liberales».

$\mathrm{Si}$ a producción científica sobre o réxime local era menor do que podía esperarse, a producción máis concreta en materia de Mancomunidades locais aínda foi moito máis cativa. Mancomunidades provinciais, publicado en Reus no ano 1914, por Xosé Gascón y Marín, daquela catedrático de Dereito administrativo da Universidade de Zaragoza, foi practicamente o libro de uso común por todos aqueles que quixeran ter un coñecemento sinxelo, pero certamente moi detallado, do novo organismo supraprovincial. Poden rastrearse citas concretas en obras sobre o rexionalismo, pero non hai unha adicación científica permanente e monográfica a un tema que era motivo de disputa entre diferentes sectores.

Na Universidade de Santiago non se abordou o estudio da Administración local cos mesmos pulos con que se emprendera o estudio do rexionalismo por Alfredo Brañas e Salvador Cabeza de León. A morte de Brañas influiu inevitablemente na baixa da producción intelectual sobre o rexionalismo en Galicia. O mesmo Salvador Cabeza de León, máis pre- 
ocupado pola investigación histórica, sobre todo afanado na elaboración da monumental Historia de la Universidad de Santiago, irmán da Historia de López Ferreiro, tampouco adicou moito esforzo á comprensión de novas estructuras nas que se agochaba máis ou menos descaradamente a idea rexional, pola que tanto él como Brañas loitaran durante moi longo tempo.

Desde o ano 1876, por mor do malfadado Real Decreto do 12 de febreiro, non se presentaban teses de doutoramento nas Universidades periféricas. Estaba anulada a posibilidade de que moitos novos licenciados puideran adica-las súas preocupacións investigadoras á análise de feitos que Galicia estaba a vivir seguindo a liña trazada polo catalanismo. As veces, sin embargo, nalgunha tese presentada en Madrid hai algunha referencia específica ás Mancomunidades provinciais.

Concretamente, nunha nota a posteriori, da Memoria doutoral de Luís Porteiro, defendida o día 4 de outubro de 1913, en Madrid, hai unha referencia moi concreta ás Mancomunidades provinciais. Despois de lembrar no texto a necesidade dunha política descentralizadora, iniciada por Maura e Canalejas, Porteiro refírese na nota ó Decreto de Mancomunidades, no que, como explica, o Gabinete Dato «siguió la orientación iniciada por el señor Maura».

García Acuña, Peña Novo e a aspiración da mancomunidade galega Desde dúas liñas periferistas moi diferentes, Xosé García Acuña e Luís Peña Novo fixeron algunhas aportacións á parca bibliografía sobre as mancomunidades provinciais. Xosé García Acuña fixo a carreira de Dereito en Madrid, mentres que Peña Novo estudiou en Santiago e foi profesor durante moi pouco tempo, da man de Luís Porteiro. García Acuña partía dun idearium rexionalista non aceptable polo nacionalismo de Irmandades da Fala, mentres que Luís Peña Novo era un dos máis influintes definidores do seu programa. Seguindo indirectamente a liña maurista, García Acuña refuga as Mancomunidades provinciais, porque coida necesario ir a unha reforma da Administración local na que as provincias e municipios teñan previamente autonomía e poidan emanciparse da tutela gubernativa. Para Peña Novo, a Mancomunidade non é aceptable por si mesma, senón en canto sexa un camiño para ir cara a autonomía integral.

O ton crítico é moi diferente en García Acuña e en Peña Novo. De creer a García Acuña, as súas palabras foron escritas a rentes da publica-

"CUADERNOS DE ESTUdIOS GALLEGOS", Tomo XLIII, Fascículo 108, Santiago 1996. 
ción do Real Decreto das Mancomunidades provinciais, no ano 1914, se ben o libro El Regionalismo, de Charles-Brun, no que publicou tales reflexións, non acadou estado público ata o ano 1918. Sin dar demasiada marxe á instalación do sistema mancomunitario, o diplomático betanceiro desvalorizou rotunda e duramente a experiencia: «A la hora en que estas líneas se escriben van transcurridos ya bastantes meses desde que la reforma de puso en vigor, tiempo suficiente para afirmar su total fracaso, a excepción de la Mancomunidad catalana, que, sin embargo, tampoco parece muy pujante y vigorosa».

García Acuña non regateou figuras retóricas para impugna-la innovación descentralizadora: «...vio la luz, con ayuda e intervención quirúrgica y en parto prematuro y artificial, encarnada en un enclenque y desmirriado Real decreto, del que a estas horas ya nadie hace caso en España». Antes de que foran dotadas de autonomía e libres da tutela gubernamental, as provincias e concellos «se les hizo el regalo de la flamante clámide de la Mancomunidad, insuficiente para cubrir la desnudez de sus formas inertes y de sus miembros sin vida, tal como si a un cesante famélico que el caciquismo pusiera a pedir por puertas, se le hiciera el don del más coruscante uniforme del Jefe superior de Administración». Peña Novo, en cambio, desde unha instalación nacionalista, moito máis que unha crítica, estaba interesado en espalla-la forma de aplicar transitoriamente o modelo, por se chegaba o día en que puidera servir de arranque para a conquista dunha autonomía integral para Galicia.

Luís Peña Novo xogou un doble papel no esforzo de implantación da Mancomunidade galega entre os anos 1913 e 1923. Formalizou un modelo doctrinal de Mancomunidade galega, seguindo a pauta da de Cataluña, para o caso imprevisible de que algún día fóra necesario implanta-la. No ano 1922, tivo un papel moi activo na Asemblea de Concellos e Deputacións provinciais, en representación do Concello da Coruña, no que era concelleiro, elexido o ano 1918. A súa gran preparación xurídica e unha preocupación cuidada con lecturas de ultima hora pola socioeconomía de Galicia, dáballe, asi mesmo, a posibilidade de intervir moi activa e eficazmente na formulación do pensamento nacionalista galego en relación co librecambismo, en contra do proteccionismo con que o Estado español aseguraba os intereses de Cataluña ou dos trigueiros de Castela.

"CUADERNOS DE ESTUDIOS GALLEGOS", Tomo XLIII, Fascículo 108, Santiago 1996. 
Na dimensión teórica, La Mancomunidad gallega é practicamente o único libro escrito en Galicia sobre o organismo supraprovincial establecido en Cataluña no ano 1914. O libro foi escrito no mes de xuño de 1921 e publicouse en xullo de 1922. Chegaba, polo tanto, serodiamente desde unha perspectiva das aspiracións e das utopías, pero chegaba a tempo desde a perspectiva das dificultades con que se atopaba a idea autonómica. Existían xa outras propostas de superación, como a autonomía integral, polo menos para Cataluña, pero en Galicia non se avanzaba na creación dunha conciencia nos órganos administrativos que puidera nin siquiera permiti-la creación da Mancomunidade provincial. Entendido como un libro para unha situación transitoria, sin pretensións de permanencia científica, é un resultado dunha acomodación práctica da utopía autonomista sin renunciar á utopía da autonomía integral. Explica Peña Novo a necesidade de crear un organismo rexional con ampla autonomía, pero que non terá desgraciadamente unha solución inmediata. Soamente na marxe que o lexislado ofrece se pode actuar: «Y este margen es la facultad de poder crear la Mancomunidad de las provincias»

Con La Mancomunidad gallega gañou Peña Novo o «Primer Concurso sobre temas interesantes para Galicia», convocado pola Revista Mondariz, que editaba o Balneario do seu nome, propiedade dos Peinador, vencellados moi estreitamente ó nacionalismo galego. Foi publicado logo na Imprenta M. Roel de Vigo, si ben non ten data de saída do prelo. O libro ten unha finalidade práctica, como sinala o propio autor cando se refire ó «carácter eminentemente práctico que desde el principio quisimos darle». Pretende darlle carácter xeral, para orientar ós futuros gobernantes de Galicia, «dándoles normas de solución para sus problemas, estudiándolos en su aspecto de eficacia gubernamental». Esta finalidade práctica exclúe, en principio, aspiracións científicas e a utilización dunha metodoloxía científica. En principio, cabe sinalar que as referencias bibliográficas son mínimas. Xosé Gascón y Marín ou Cubí non se mencionan, aínda que, cando menos o primeiro era fonte obrigada de consulta, e, probablemente, foi fonte tamén directa deste libro. Soamente se utiliza en forma abundante o traballo de Alfredo Pereña presentado na Semana Municipalista de Barcelona, para describi-lo funcionamento dos concellos rurais. As citas de carácter xeral sobre descentralización, de Paul Boncour e de León Duguit, que se fan inicialmente, non se continúan logo ó longo do texto. 
Non son raros os libros de eséxese ou de recetas políticas na historia do pensamento político. Os consellos ó príncipe foron esforzos de intelectuais que tentaron de moviliza-la acción política dun xeito voluntarista. Así como pensadores clásicos acudiron a textos bíblicos, Peña Novo convertiuse nun intérprete do Estatuto da Mancomunidade de Cataluña: «Por eso me parece lo más oportuno, aunque para mi labor personal no sea lo más lúcido, pero sí lo de más práctica eficacia, traducir y transcribir el Estatuto que ha servido para la Constitución de la Mancomunidad catalana, haciéndole al final breves comentarios para su adaptación a la Mancomunidad gallega». Metodolóxicamente, La Mancomunidad gallega é unha extrapolación da experiencia da Mancomunidade catalana a Galicia, insistindo o autor en que debemos aproveitar a experiencia daqueles pobos que se anticiparon. O método comparativo serve a Peña Novo, para ir explicando aqueles aspectos e institucións que son diferentes en Galicia con respecto a Cataluña é que non poden ser traducidas a normas en Galicia nin a unha política galega. O sistema parroquial, por exemplo, adica especial importancia, como base da organización administrativa de Galicia.

Un feito paradóxico estivo a punto de achica-la distancia entre a intención práctica e a utopía da Mancomunidade galega no ano 1922. Por mor dun debate intenso e desgarrado entre forzas políticas, polos gravames que Francisco Cambó tentou de introducir sobre o millo, suscitouse a posibilidade de implantar unha Mancomunidade galega, que asistira a Galicia como unidade. O libro de Peña Novo acadaba, deste xeito, inesperada actualidade. Da doctrina e das fórmulas científicas incorporadas no libro, Peña Novo pasou á acción. Sin perde-la fe na autonomía integral, defendía circunstancialmente a Mancomunidade galega, como única fórmula posible para que Galicia puidera expresa-la súa personalidade pública e colectiva dun xeito unitario.

\section{A práctica e a posición doctrinal de Peña Novo}

Peña Novo divide La Mancomunidad gallega en tres partes. As aplicacións que fai a Galicia de cada materia estudiada, permitenlle supera-la función sinxelamente esexética, para converti-lo libro nun dos mellores productos da cultura política galega. A perspectiva política dos asuntos socioeconómicos non tiña desde Alfredo Brañas un pensador axeitado ata que Peña Novo deulle unha nova luz, superando e traducindo algunhas aspiraciones do rexionalismo en fórmulas nacionalistas de Irmandades da Fala.

"CUADERNOS DE ESTUDIOS GALLEGOS", Tomo XLIII, Fascículo 108, Santiago 1996. 
A primeira parte está adicada ós medios para que as provincias galegas establezan a Mancomunidade na orde económica, recadando do poder central certas reformas tributarias co fin de que teñan eficacia positiva, como titula literalmente. Despois de refuga-lo centralismo provincialista, describe os precedentes da Mancomunidade, como unha idea que «no es nueva en el Derecho español», podendo, quizais , advertirse neste aspecto precisamente o eco de Posada ou de Gascón y Marín. O capítulo adicado ós aranceis, aspecto que terá gran repercusión política, é un dos mellor trazados de todo o libro, no que, por outra parte, se separa da política catalana e manifesta a peculiaridade de Galicia.

A parte segunda está adicada ós traballos que deben realizarse para que a Mancomunidade chegue a construi-los camiños veciñais, estradas, tranvías, trens e outras obras públicas que o fomento da riqueza requira. Xa cos medios precisos, desposita nas súas mans o futuro desenvolvemento do progreso da terra, mediante a realización dunha serie de servizos, entre os que os máis urxentes son as vías de comunicación, a agricultura, a vida marítima e o ensino, sectores ós que adica especial atención.

A terceira e derradeira parte de La Mancomunidad gallega está adicada ó sistema de administración que a Mancomunidade galega debe establecer. A administración debe tender a tres finalidades esenciais: rapidez, eficacia e garantía. As palabras de Peña Novo eran proféticas: «desempeñando rapidamente su cometido en un verdadero sistema de gerencia como si de una empresa particular se tratara, dando alma, en una palabra, a las actuales oficinas muertas».

O libro vai orientar ós futuros gobernantes de Galicia, «dándoles normas de solución para sus problemas, estudiándolos en su aspecto de eficacia gubernamental». Esta finalidade práctica exclúe, en principio, aspiracións científicas e a utilización dunha metodoloxía científica. As referencias bibliográficas, por exemplo, de outros autores son mínimas. Xosé Gascón y Marín ou Cubí non figuran por ningunha parte. Soamente se utiliza en forma abundante o traballo de Alfredo Pereña presentado na Semana Municipalista de Barcelona, para describi-lo funcionamento dos concellos rurais. As citas xerais de Paul Boncour e de León Duguit, por exemplo, non se continúan logo durante o texto, polo que é difícil coñecelas fontes.

"CUADERNOS DE ESTUDIOS GALLEGOS", Tomo XLIII, Fascículo 108, Santiago 1996. 
A creación dun órgano permanente, pero sen que fora un organismo novo, podía ser precisamente unha fórmula para impedi-la creación dunha Mancomunidade galega pero, Peña Novo, consecuente cos principios esbozados no seu libro, ratificouse en tódolos seus pensamentos anteriores. No proceso histórico de recepción do concepto en Galicia, primeiro aparece a autonomía integral e logo rebaixase mediante a petición dunha Mancomunidade provincial transitoria. Explicabase porque, cando aparece Irmandades en 1916, xa a Mancomunidade catalana fixo o seu Manifesto e unhas novas Bases de reforma, que provocaron unha cantidade de peticións de autonomía integral, á vista da política de García Prieto.

A diferencia entre os ideais da Asemblea Nazonalista de Lugo do 18 de novembro de 1918, e a de Santiago, e moi grande. En Lugo, procurase unha autonomía integral, tal como di a segunda das bases; pero, en Santiago, e xa unha rebaixa, pasando polo intermedio da Mancomunidade provincial. No Manifesto da Asemblea Nacionalista de Lugo, do 18 de novembro de 1918, fálase da autonomía integral, xa como autonomía política, sin pasar pola fase de descentralización administrativa local pola que pasara Cataluña. Non hai ningunha referencia á Mancomunidade galega, nin siquiera como situación transitoria, como se producirá máis tarde.

Na II Asemblea Nacionalista, celebrada no mes de novembro de 1919, e publicada-las conclusións o 15 de novembro, insístese na petición de autonomía integral, para, como estado transitorio, acabar coas Deputacións provinciais e constituir a Mancomunidade de Concellos galegos. Dada a actitude existente contra as Deputacións provinciais, os nacionalistas galegos pretenden que a Mancomunidade galega sexa unha Mancomunidade de concellos e non unha Mancomunidade de provincias, o que o distingue da realidade institucional de Cataluña de xeito que a autonomía integral non admitía nen sequera a creación a Mancomunidade galega, a imitación da Mancomunidade de Cataluña. Soamente como unha situación transitoria, camiño precisamente dunha versión integral e artellada de Galicia, facíase necesario crea-las condicións que facilitaran a creación dun organismo rexional. Non será a ultima vez, ademais, que Irmandades intensifique o seu esforzo a prol da Mancomunidade galega, como sucedeu nos anos 1929 e 1930.

"CUADERNOS DE ESTUdIOS GALLEGOS", Tomo XLIII, Fascículo 108, Santiago 1996. 
Na práctica administrativa e política local, a prevención das Deputacións provinciais ou de moitos Concellos contra unha innovación que puidera restarlle poder política era moi clara. Espoleados polas críticas de inoperancia, sobre todo contra o foco caciquil das deputacións, algunha vez xuntaronse, pero era, normalmente, para decidir con autonomía sobre aspectos comúns, como a creación do Manicomio, da Leprosería ou do Hospital antituberculoso. As xuntanzas eran soamente para aspectos sectoriais, que non implicaban ningún organismo obxectivo e supraprovincial de carácter permanente polo que sin un impulso, máis ben con freo, desde o Goberno, as Deputacións provinciais non podían inicia-la creación dun modelo supraprovincial.

As forzas nacionalistas, vencelladas entre 1917 e 1918, ó catalanismo da Lliga, replicaban tentando de establecer unha Mancomunidade como a catalana, pero xa, inspirados na política catalana, soamente se pensaba con carácter transitorio, xa que a liña política nova orientabase a prol da autonomía integral, concepto político máis expresivo das arelas rexionais de Cataluña e de Galicia. A intensificación da crítica das Deputacións provinciais, como órganos e reductos de caciquismo, así como o anceio de crear un organismo semellante ó catalán, sempre en discusión, aínda poñía máis en garda ás forzas políticas defensoras do stablishmen administrativo.

\section{O TENSO DEBATE PÚBLICO CONTRA OS ARANCEIS DE CAMBÓ E A MANCOMUNIDADE GALEGA}

\section{A incidencia dos aranceis na política mancomunalista}

Cando se estaba a elabora-la revisión dos aranceis de 1922, os deputados e senadores galegos xuntaronse na segunda sesión do Congreso, co fin de actuar conxuntamente para loitar contra os valos que se opoñían á riqueza de Galicia. En realidade, a finalidade inmediata que os convocaba era a alarma creada pola política arancelaria propiciada por Francisco Cambó, ministro de Facenda nun goberno presidido por Antonio Maura. Xa en 1917 se xuntaran no que se chamou o bloque, polo que, á vista das conclusións á que chegaran e dos resultados que acadaron, a xuntanza foi recibida con ironía polos xornais nacionalistas. En 1922, 
polo menos, a xuntanza tivo a virtude de alentar a indecisos e a forzas oficiais a prol dunha loita común contra uns aranceis que se estimaban altamente prexudiciais para o campo e para a economía de Galicia.

As reaccións contra a revisión dos aranceis producironse antes e despois da aprobación do Real Decreto refrendado por Francisco Cambó. Cando estaban a elaborarse pola Xunta de Valoracións, cundeu a alarma e o país galego empezou a decatarse de que non lle eran favorables, amosando, en xeral, unha actitude defensiva ante o que se estimaba constitutivo dun agravio comparativo. Ante a pasividade dos organismos oficiais de Galicia para reaccionar con eficacia, rapidez e contundencia, non faltaron naquel momento os que botaban de menos un organismo supraprovincial cando menos, a poder ser un organismo rexional expresivo da personalidade colectiva, que defendera os dereitos e os intereses da rexión galega. A Mancomunidade provincial, a poder ser mellor unha Mancomunidade municipal, atopou canle en sectores e en loitadores por unha Galicia dotada de forma política ou administrativa.

A política arancelaria de Francisco Cambó foi sometida a un intenso debate público en Galicia. Por un lado, interviron os agraristas en forma moi decidida, coñecedores dos problemas que se asomaban sobre o campo galego. Por outro lado, a título persoal, significados líderes políticos interviron no debate público. Como cos problemas dos consumos, das subsistencias, das carnes conxeladas, das admisións temporais de latón, etc., fórase construindo unha doctrina xeral sobre as relacións económicas co centro, chegando a unha comprensión librecambista das relacións, porque diste xeito evitabase que as rexións máis favorecidas impuxeran a política económica.

Antes da promulgación do Real Decreto de 12 de febreiro de 1922, expresaronse varios intelectuais, científicos e políticos. O 30 de xaneiro de 1922, Xoan Xosé González, dirixiuse os galegos baixo o título Nuestra región amenazada. $\mathrm{O}$ socialista galeguista compostelano dicía: «De dos modos se perjudica grandemente al pueblo gallego en esta ocasión; ellos son: la importación del maíz, producto que Galicia tiene que admitir en sus mercados con gravamen abrumador, y las carnes frescas y congeladas que vendrán a la nación española, es decir, al mercado nacional para ser vendidas con más ventaja que las de aquí, quedando con ello la industria ganadera de Galicia, muerta y sin porvenir». 
Coñecidos políticos en activo, desde distintas perspectivas, interviron na polémica. O Marqués de Figueroa publicou o 6 de febreiro un longo artigo titulado Galicia y el Arancel, reproducido en El Sol o día 9. O político compostelano, maurista decidido, pero pouco camboista, co acento agrarista conservador que o caracterizaba, explicou: «La región gallega, durante mucho tiempo, como pocas pacífica, se halla en la actualidad hondamente perturbada. Si lo que ocurre allí ocurriera en otra cualquier parte de España, habría copiosísima información; pero Galicia vive aparte, en aislamiento material y moral». Fondamente perturbada, era unha expresión que acadaba moi ben para o estado en que se atopaba Galicia. Pero, a expresión sobre a información, podía ser tanto unha comparación con Cataluña, como un laio sobre a deixación de moitos galegos por falta de coñecemento real da situación. O Marqués, ex ministro con Maura, lanzaba un consello práctico: «Rectificando ahora, se evitarían muchos males, incluso el de volver sobre esto en cuanto se publique el Arancel, tan pronto como se abran las Cortes». E remataba: «En la no protección del Arancel está, para el caso, la verdadera protección». A forma deixaba trasluci-lo seu pensamento, concretando a súa oposición á política arancelaria de Cambó.

Publicado o Real Decreto, os contrarios ós aranceis para Galicia non se deron por vencidos, xa que confiaban na decisión última para cando se abriran as Cortes. No debate público, co fin de que derrogase o Real Decreto, interviron xentes moi diversas. Gracias a esa teima con que algúns tomarón o asunto dos aranceis do millo, puideron ver como se modificaban os aranceis pola Lei do 10 de xuño dese mesmo ano de 1922.

Entre os máis decididos loitadores contra o perigo dos aranceis para Galicia, destaca Bartolomé Calderón, tanto pola súa ilustre personalidade como pola continuidade da súa campaña. Desde París, onde tiña a súa residencia habitual, adoptou unha actitude crítica non soamente contra os aranceis do millo, senón contra os efectos de todo o dispositivo arancelario que afectaba á economía agraria de Galicia. $\mathrm{O}$ arancel era un perigo integral, especificando o día 19 de febreiro que: «Todas o casi todas las materias indispensables han sido gravadas, incluso el carbón de piedra y las lanas».

Desde as filas liberais, Bernardo Mateo Sagasta, deputado por Caldas de Reis, ben coñecido polo seu labor como xefe de agricultura de 
Pontevedra e ex Subsecretario de Facenda, publicou un longo artigo, reproducido en El Compostelano, do 15 de febreiro de 1922, titulado expresamente Anomalías arancelarias, reproducido en El Imparcial do día seguinte, no que sintetiza que: «Ha sido constante aspiración de Galicia la libre importación del maíz». Trata de razonalo feito de que a liberdade arancelaria con respecto ó millo en Galicia non afectaba en absoluto á súa base.

\section{Peña Novo e o arancel centralista}

Luís Peña Novo publicou, o día 1 de marzo de 1922, un artigo titulado O problema arancelario, á porta mesmo da Asemblea de Deputacións provinciais e Concellos, que se celebraría o día 5. «En xeneral - dicía o líder nacionalista-, o arancel centralista, sinon tódo-los da Aduana hespañola, son para Galicia á maneira de colunas barométricas que van marcando gradualmente a nosa miseria; pero ademais son un padrón de vergonza e inominia, un verdadeiro estigma de pobo colonizado; toda a nosa economía rende tributo a tóda-las demais economías hespañolas». Debido á carestía de cereal, os labregos teñen que adicar 450.000 hectáreas de terreo ó cultivo do trigo, do millo e do centeo, «cultivo antieconómico pero que ten que atender non por comenencia sinón pór necesidade derivada do arancel», concreta Peña Novo.

A campaña pública, en casi tódo-los xornais, estivo acompañada por acordos e telegramas dos Concellos, dirixidos directa ou indirectamente a Francisco Cambó. O Concello de Santiago remitiulle telegramas a deputados e senadores. Cambó contestoulle a Miguel Gil Casares lacónicamente: «Reserva me obliga cargo, me impide contestar tal desearía su telegrama». O telegrama do Concello compostelano dirixido a Cambó, dicía así: «Ayuntamiento Santiago, ruega V.E. tenga presentes intereses región gallega para rebajar tipo gravamen introducción maíz, por ser base alimentación labrador y ganadería. Debo indicar V.E. que hoy alcanza precio subido ese cereal por causa aumento jornales y disminución horas de trabajo, y si además se recarga tributación será imposible la vida del sufrido campesino gallego».

O esforzo non será totalmente van, por unha vez. Sendo xa ministro de Facenda Bergamín, primeiro en contra de calquera modificación, pero logo presionado polos senadores galegos, sobre todo pola decidida actuación de Pan de Soraluce, foi posible un cambio, dificilmente conseguible 
de seguir Francisco Cambó ostentando a carteira de Facenda. A Asemblea de Deputacións e Concellos de Galicia, celebrada na Coruña, foi unha das bases con que os senadores puideron alegar o estado de alarma existente na opinión pública galega. A intención de Luís Peña Novo era a de matar dous paxaros dun tiro, tentando de cambia-lo sistema arancelario, mediante unha comprensión do carácter librecambista de Galicia e, ó mesmo tempo, de procurar unha Mancomunidade rexional para Galicia, de base municipal preferentemente, pero provincial como mal menor, se ben non se cumpriu nos termos con que o notable líder irmandiño pretendía.

\section{A ASEMBLEA DE DEPUTACIÓNS E CONCELLOS DE GALICIA DE 1922}

\section{Unha política común e o xermolo da institucionalización manco- munalista \\ Co fin de adoptar unha política común, xa que o asunto afectaba a} toda Galicia, concibiuse a idea de organizar unha Asamblea de Deputacións e Concellos de Galicia. No fondo, tal como se denunciou no seu tempo, era unha xuntanza que tiña como finalidade específica a de arroupa-las xuntanzas que tiñan nas Cortes os deputados e senadores elexidos por distritos ou corporacións de Galicia. A Nosa Terra, o 15 de marzo de 1922, criticou con dureza a Asemblea das Diputaciós e Concellos. Sinalou que: «A Asembleia foi convocada para apoiar dende eiquí aos parlamentarios galegos que están en Madrid facendo o burro en col d'estes asuntos e de tódo-los que a Galicia se refiren». A Asemblea non tiña por obxecto a creación dunha Mancomunidade provincial, como dixeron algúns xornais, pero houbo quen sembrou a idea, como fixo Luís Peña Novo durante os debates e logo no banquete.

A iniciativa da xuntanza das Deputacións tomouna Ramón Vilas González, presidente da Deputación provincial da Coruña e leal á Manuel García Prieto. No fondo era unha fórmula máis para vulnera-la política seguida por Antonio Maura, atacando directamente a Francisco Cambó como membro do seu goberno. Conformes coa súa invitación ós presidentes de Lugo e Pontevedra, acordouse a xuntanza para o día 5 de marzo, ampliando a invitación ós Concellos e a outras corporacións, como 
algúns sindicatos, celebrándose en tal data no Pazo Provincial da Coruña. A mesa presidencial estaba integrada interinamente por Vilas, Basanta Silva, vicepresidente da Deputación de Lugo, e Casas Medrano, deputado provincial e membro da Permanente da Deputación provincial de Pontevedra.

O presidente da Deputación de Pontevedra non puido asistir, pero enviou un saúdo e a súa delegación en Ramón Vilas para solicita-la libre importación do millo. Varios deputados a Cortes estaban presentes na xuntanza. Polo Concello de Santiago, estaban presentes o alcalde accidental, García Ferreiro, e o secretario, Rodríguez Montero. Doutros concellos, como Vigo, Ferrol, Sada, entre outros, habia tamén representación. O Concello da Coruña estaba representado polo seu alcalde, González Rodríguez, e polos concelleiros Suárez Ferrín, Paredes, Fontenla e o secretario Martín. Desta delegación do Concello da Coruña formaba parte, tamén, Luís Peña Novo, coa congratulación da fracción nacionalista de Irmandades da Fala da Coruña, pero coa opinión adversa da Irmandade Nacionalista de Ourense, a quen dicían non representaba, e que soamente o aceptaban como concelleiro nacionalista. Deuse conta de numerosas adhesións de concellos das provincias de Coruña, Lugo e Pontevedra.

Vilas González pronunciou un longo discurso, no que se refiriu ó agravio inferido a Galicia nos novos aranceis, gravando desconsideradamente o millo, malia de tóda-las reclamacións feitas e contra as xestións dos parlamentarios primeiro ante a Xunta de Valoracións e logo ante o ministro de Facenda. Sinalou que, malia das 340.000 toneladas que entraron desde 1912, a rexión ten un déficit de 100.000 toneladas, con ser como é productora de millo. Pidía opinións sobre si conviña un réxime de excepción absoluta de dereitos ou as admisións temporais de millo, como se fixo outras veces, ou un pago acomodado a dereitos, fixando o límite discreto do que puidera pagarse.

Xoan Rof Codina inclinouse pola desgravación absoluta e duradeira, para que os campesinos galegos poidan evolucionar abandonando o cultivo do millo e adicando os terreos á prado e forraxes. Destacou a irritante desigualdade que no arancel existe para favorecer ás Vascongadas e a Cataluña. Sinalou que cando se permitiu a libre importación do millo, Galicia exportou gando.

"CUADERNOS DE ESTUDIOS GALLEGOS", Tomo XLIII, Fascículo 108, Santiago 1996. 
Despois das intervencións dos alcaldes da Coruña, Sada e Santiago, o discurso de Luís Peña Novo deulle unha nova orientación á Asemblea, abordando un aspecto que latía no seo dela, pero que ninguén prantexaba axeitadamente, como era o da Mancomunidade rexional. Propuxo, tamén, que as exencións se estenderan a outros artículos, como augas minerais, carnes conxeladas, folla de lata. Patentizou a enorme importancia que pode tela Mancomunidade rexional. A Nosa Terra comentou gabanciosamente a participación de Rof Codina e de Peña Novo na Asemblea, destacando nos discursos deste a afirmación da Mancomunidade galega como única forma para recoñecela personalidade galega.

O presidente propuxo a formación dunha comisión dictaminadora, co encargo de que se presentaran unhas conclusións a discutir logo pola Asemblea. A comisión aceptada estivo integrada pola Mesa, formando parte dela, polo tanto, o presidente Vilas, Victor Basanta e Antonio Casas Medrano, así como polos asembleístas Federico Maciñeira, alcalde de Ortigueira; Anxel Aperribay, deputado provincial da Coruña; Luís Peña Novo, concelleiro da Coruña, e Xoan Rof Codina, representante do concello de Outeiro de Rei. Reunidos desde as tres e media do serán, ás cinco puideron dar por rematada-las conclusións. Oito foron as longas conclusións á que chegou a Comisión, que foron lidas por Vilas González. Despois dunhas aclaracións, fóron aprobadas por unanimidade. Acordouse remitir telegramas ó presidente do Consello de Ministros, presidentes das Cámaras lexislativas, Ministro de Facenda, formulando a protesta e dando conta das conclusións, dacordo coa conclusión sesta: «Que de los acuerdos de esta Asamblea se de cuenta al presidente del Consejo de Ministros, ministro de Hacienda, presidentes de las Cámaras y parlamentarios de Galicia, comprometiéndose, las Diputaciones y Ayuntamientos a gestionar sus respectivos representantes en Cortes su cooperación y apoyo para la consecución de los fines de esta Asamblea».

O Concello da Coruña obsequiou ós asistentes cunha cea íntima no Hotel Palace, o domingo, día 5, pola noite. O luns, ó mediodía, o presidente da Deputación provincial da Coruña, agasallounos cunha comida, no mesmo hotel. Aproveitando a súa presencia na Coruña, foi especialmente invitado don Salvador Cabeza de León, que o domingo pronunciara unha conferencia sobre «La Sociedad de Naciones como instrumento de paz. Su eficacia real», no curso de extensión universitaria organizado pola Reunión de Artesanos. Non consta que intervira no xantar dos asembleistas, o que non deixa de ser curioso.

"CUADERNOS DE ESTUDIOS GALLEGOS", Tomo XLIII, Fascículo 108, Santiago 1996. 
Na hora do brindis, Xoan Rof Codina comezou desexando que os traballos tiveran continuidade e que debía fixarse xa a data da próxima asemblea, pero xa sobre a base das conclusións das Asembleas Agrarias iniciadas en Monforte e non sobre o arancel unicamente. Referíuse á necesidade de construír camiños e ó aproveitamento dos montes. Despois dun saúdo do alcalde da Coruña, o de Neda propuxo que se invitase ós sindicatos agrarios, pero na súa quenda Peña Novo mostrouse contrario a esta idea. Peña avogou pola construccións de ferrocarrís, expuxo a necesidade de instalar sucursais do Banco de España en América, como unha custión interesantísima para os galegos aló residentes. Vilas González destacou a importancia do acto do domingo e destacou, entre as iniciativas, a rede telefónica provincial. Rof Codina engadiu a necesidade de atendelas comunicacións provinciais, ampliando a rede de camiños veciñais. En termos semellantes se expresou o alcalde da Coruña.

Peña Novo falou en galego, para destacar que ó éxito da Asemblea era un gran paso a prol da Mancomunidade provincial e municipal galega. Era a única voz que falaba en favor da Mancomunidade provincial, pero, no seu discurso, deslizou, tamén, a idea da Mancomunidade de concellos, aspecto defendido por Irmandades da Fala, opostos totalmente a pervivencia das Deputacións provinciais.

\section{As conclusións da Asemblea}

A Comisión dictaminadora presentou ante a Asemblea de Deputacións e Concellos galegos en 1922 as conclusións. As tres primeiras refirense dun xeito concreto ó problema inmediato, como era o dos aranceis do millo. A cuarta, máis que unha conclusión, podería se-lo preámbulo das conclusións, porque nela se tenta de explicalos principios en que se basean as conclusións aprobadas. A quinta acolle o principio sustentado por Calderón desde París, no senso de que os prexuicios do arancel afectaban a toda a economía galega. A sesta era un mandato para dirixirse ás autoridades para facerlles chegalas conclusions, o que así se fixo, polo que foi unha das que puido cumprirse de inmediato. A sétima e a octava propoñían a creación dun Comité permanente e a constitución da Asemblea con carácter permanente.

Si se compara a linguaxe utilizada por Peña Novo nos seus artigos sobre libre importación do millo e dos seus discursos, hai conclusións que foron practicamente resultado da súa redacción. A conclusión octava 
parece se-lo resultado dunha transacción entre o seu pensamento da implantación da Mancomunidade rexional e a creación dun organismo permanente que, sin cambia-la estructura xurídica das Deputacións provinciais, permitira cando menos unha actuación conxunta. Non existen referencias concretas ó traballo interno da Comisión dictaminadora, polo que hai que facer unha operación esexética para chegar a estas conclusións.

Ás cinco do serán do luns, a Asemblea volviu a xuntarse para debatelo dictame elaborado pola Comisión dictaminadora. A primeira conclusión era unha protesta contra o procedemento e a desconsideración ó non escoitarse a voz da representación galega no Congreso: «Protestar enérgicamente de la desconsideración que supone el nuevo Arancel para los intereses de Galicia, que coinciden a su vez con los nacionales, desconsideración más patente por haberse elevado en algún caso los derechos arancelarios propuestos por la Junta de Aranceles y Valoraciones, después de que por parte de los organismos autorizados de la región y en el Parlamento se habían practicado gestiones encaminadas a la desgravación de algunos artículos como el maíz».

A segunda conclusión formulaba o problema da sustitución das terras de millo polas de prados: «Declarar que es problema que afecta esencialmente a la vida económica y social de la región gallega, lo que respecta a la desgravación total y permanente del maíz y piensos concentrados, esto es, la libre introducción de unos y otros, o cuando más con un pequeño impuesto para efectos de estadística solamente; sin que en ningún caso pueda alegarse, que la cuantía señalada por el nuevo Arancel no tienen importancia como recargo sobre el valor de la mercancía, porque es aspiración unánime impuesta por la realidad que la adquisición del maíz y piensos concentrados se ofrezcan en términos de que el agricultor no precise dedicarse a la producción de aquellos por ser ruinosa y porque en los casos en que hubiere necesidad de aplicar la tarifa primera de los Aranceles, el impuesto de seis pesetas que estos señalan envuelven un gravamen que hace imposible la adquisición de dichas mercancías».

$\mathrm{Na}$ terceira pidese a rebaixa do centeo: «Que las comarcas gallegas que consumen centeno, a pesar de ser productoras de este cereal, aspiran a que sean rebajadas en forma sensible los derechos que señala el nuevo Arancel». A cuarta ten carácter descritivo da situación e explica a realidade do problema: «Que con la desgravación total del maíz y piensos concentrados y la rebaja de los del centeno, no se produce disminución en los 
ingresos del erario público, puesto que con los derechos que se han señalado en el nuevo arancel no cabe el realizar considerables importaciones, como lo demuestran las estadísticas de Aduanas, mientras que, despareciendo los gravámenes y llevándose a cabo por lo tanto grandes importaciones, la ganadería adquiere rápido desarrollo, se entrega al consumo un contingente grande de productos pecuarios de primera necesidad (carne, leche, cueros, lana, etc.etc.) y se aumenta la riqueza del campo que contribuye a las cargas e impuestos que por otros conceptos se hallan establecidos».

A Quinta refíre-se a concepción integral, defendida por Bartolomé Calderón: «La unánime aspiración expuesta es solo el mínimo de reformas arancelarias que la economía gallega exige, con inexcusable urgencia y necesidad absoluta, pero la Asamblea reconoce que en dicha reforma aparecen no sólo desamparadas sino gravemente perjudicadas las principales fuentes de la riqueza gallega, como son la industria conservera, vinos, aguas medicinales y de mesa, condenadas a una crísis próxima por el enorme gravamen establecido en la introducción a la hoja de lata y de botellas vacías, amén de otras industrias también perjudicadas». A sesta das conclusións xa está exposta anteriormente.

\section{Un órgano permanente en vez dunha mancomunidade}

Os esforzos de Luís Peña Novo a prol da creación da Mancomunidade provincial ou municipal de Galicia non tiveron éxito. Soamente, como sustitutivo funcional, para que as conclusións foran efectivas, puido conseguir que se constituira un Comité permamente e que a Asemblea se constituise con carácter permanente. A Conclusión Sétima facultaba para crear un Comité Permanente e executivo, para realiza-las xestións necesarias,constituíndose en Madrid, se o cre-sen necesario, para o cumprimento dos fins da Asemblea. A octava, na medida en que podía se-lo xérmolo e o anticipo dunha posible Mancomunidade provincial, dicía literalmente así:

«Considerando que la actuación de las corporaciones asistentes y representadas en la Asamblea no debe limitarse a los fines objeto de su convocatoria, sino que también deben continuar interviniendo en todos los demás asuntos de interés general para la región, unos que ya están planteados actualmente, y otros que puedan promoverse en lo sucesivo, declara la Asamblea que ésta queda constituída a tales efectos con carác-

"CUADERNOS DE ESTUdIOS GALLEGOS", Tomo XLIII, Fascículo 108, Santiago 1996. 
ter permanente, hasta la primera Asamblea que haya preciso celebrar, teniendo como órgano que la represente el Comité que se designe conforme la base anterior».

A novena conclusión, pola súa banda, dicía que: «La Asamblea se significa en el sentido de que los organismos reunidos están decididos a utilizar todos los medios legales y asistenciales precisos á conseguir la efectividad de las presentes conclusiones, adoptando las determinaciones que sean procedentes». A creación dun órgano permanente, pero non de un organismo novo, como pretendía Peña Novo, era xa o anticipo do destino que lle esperaba. O Comité foi constituido, a proposta do Alcalde de Santiago, polos catro presidentes das Deputacións provinciais e os Alcaldes da Coruña, Pontevedra, Lugo e Ourense, baixo a presidencia de Vilas González.

Despois dalgunhas precisións dos representantes de Santiago, Ortigueira, Ferrol, Neda e Coruña, o dictame da Comisión foi aprobado por unanimidade. A euforia da xuntanza e dos banquetes, logrou o fin inmediato de reunilas forzas galegas nunha manchea, tamén en algún aspecto en relación coa demora nos aranceis, pero non serviu para alimentalo senso de unidade rexional e, moito menos, de resolvelo problema sempre pendente daquela sobre a imposibilidade da experiencia galega da Mancomunidade provincial. A fórmula aínda terá, co tempo, unha nova oportunidade, pero, en calquera caso, o que estaba claro era que Galicia necesitaba unhas estructuras de alcance territorial único, desde as que puidera manifestar e codificala súa propia persoalidade.

\section{A SUPERACIÓN NO MANCOMUNALISMO POLA AUTONO- MÍA INTEGRAL EN 1918}

\section{Entre Peña Novo, Porteiro e o Manifesto de Lugo de 1918}

Irmandades da Fala acordou celebrar no outono de 1918 unha magna asemblea. Luís Porteiro, como Peña Novo, Viqueira, Villar Ponte, Quintanilla, estaban a deseña-las liñas mestras dos puntos que o programa debía conter como expresión dun novo modelo de interpretación da vida galega. Por mor da gripe, sen embargo, deixarona para o mes de novembro. A tal aprazamento se refire Antón Villar Ponte o día 15 de novembro de 1918: «Axiña se publicará un manifesto das 'Irmandades' 
que já agora coidábamos téremos espallado pola nosa terra más que por mor do aprazamento da Asambleia de Lugo debido ao andacio grippal, non ficará feito até que aquela trascendental Asembleia - sinalada para o próisimo día 17 ¿día de groria?— o formule, estude e dispoña». Peña Novo, Cabanillas, Quintanilla, amosaban unha especial interese polos traballos. Entre tanto, o 27 de outono de 1918, no ano da gripe, Luís Porteiro Garea tivo o seu pasamento. Unha carta dirixida a Luís Peña Novo, sen embargo, aínda que non sexa moito, pode dar idea do interese que tiña o líder santiagués pola definición do modelo nacionalista de Galicia. A simple comparación de textos de Porteiro e do Manifesto revela que, en efecto, había algúns cambios, pero non tantos como para que supuxera unha radical disección con respecto ó pensamento de Porteiro. Dille a Peña Novo: «Lín a túa carta. Paréceme ben, definitivamente ben, rematadamente ben o que me dís dos traballos que vades levar á Asambreia de Lugo». Porteiro, ó mesmo tempo, dille que «eu tamén estou faguendo un cuestionario e nel tratará os puntos que reseña, pero que poden compararse co documento final aprobado polos membros que asistiron a tan importante xuntanza». En calquera caso, estimaba que «penso que ten que ser unha cousa moi forte, moi radical (no senso nazonalista) pro moi ampla e desinteresada».

Ademais da declaración previa, o Manifesto consta de sete partes, subliñadas como problemas constituíntes, problemas políticos, facultades do poder galego, cuestións xurídicas, problemas económicos e aspectos artísticos. Son medio cento de propostas, artelladas dentro de cada capítulo ou parte. A sistemática seguida non é sempre demasiado clara, porque hai cousas que poden situarse en calquera dos apartados. A ausencia de Porteiro, tanto na redacción do documento, como nas intervencións na asembela, foi decisiva para a formulación do programa, pero, a carta póstuma, malia da súa brevidade, pode axudar a esculca-las posibilidades do seu pensamento de poder participar nos traballos daquela que moi ben puidera ser definida como unha convención constituínte. Tan constituíntes que algúns dos conceptos, como o de poder galego, pasou ó Estatuto de Autonomía para Galicia de 6 de abril de 1981.

Cabanillas fixo unha síntese do acontecido na Asemblea de Lugo e un resume do Manifesto aprobado. Nunha cata dirixida a Raimundo Riestra o día 25 de novembro de 1918, emocionado, dille: «Procramamos a soberanía estética de Galicia, postos de xoenllos, non soio diante o tesouro 
dos nosos moimentos, sinon, ó par, do milagre dos nosos paisaxes; pedimos, á veira da do home, a igoaldade dos dereitos pra esta admirable muller galega; abrímo-los brazos garimosos cara a nobre Lusitania; ruximos contra do caciquismo asoballante, intresando unha lei de esceición que poña ó amparo da legalidade o noso dereito cidadán; pratenxamos o recoñecemento da persoalidade da parroquia, o municipio - impuxemos o acabamento das Diputaciós provinciás, extranxeirismo sin senso, solimán que envenenou a vida nazonal; conquerimos que se decrare istrumento de traballo, polo tanto inembargable o ocruncho da terra que o pequeno propietario percisa pra sosteñimento do seu fogar, libertando un bo anaco da patria das maus lagarteiras de curiales e foreiros; pedímola cooficialidade coa castelán desta nosa fala galega que ten dereito a ser eterna, aunque non fora máis que porque soupo ser canteira onde arrinca o idioma da Hespeña as verbas máis alumeantes; e, dimpois de votar medio cento máis de concrusións, xuramos solenemente, polo que máis queremos neste mundo e no outro, ser dos bós e xenerosos,descrarándonos dentón pra sempre nazonalistas galegos».

Vicente Risco insistirá en numerosas ocasións en que o Manifesto de Lugo de 1918 non era máis que un programa político, unha parte soamente do programa total do nacionalismo galego. No Programa do nacionalismo, publicado en A Nosa Terra, do día 1 de maio de 1931, dicía que o nacionalismo galego abrangue moitísimo máis que o dun programa político, porque abrangue a unha tódolos ordes da cultura, entendida ésta como todo aquelo que o home engade á natureza, ou seña, a totalidade da obra humán. Deste xeito, Risco proponse a galeguización total de Galicia, da súa escola e do ensino, da ciencia e da literatura, da Eirexa e da política, do comercio e do traballo, da arte e da economía, da sociedade e dos costumes, da casa e da paisaxe, da imprenta e do púlpito, da moral e do dereito, do gusto e da moda, da vida púbrica e da vida privada, do fogar, do sangue e dos osos, do pensamento, do sentimento e da vontade. A carón do programa polìtico de Lugo, segue a dicir Risco, teríamos que pór un programa social, un programa cultural, un programa moral, un programa estético, un programa pedagóxico.

Ollemos algúns daqueles elementos que constitúen o fundamento daquel importante documento político, comparandoos cando sexa posible, coa carta póstuma de Luís Porteiro. En certos casos, as ponencias de Villar Ponte ou os escritos de Xoan Vicente Viqueira poden facilitala comprensión dunha presencia espiritual de Luís Porteiro na Asemblea de Lugo.

"CUADERNOS DE ESTUdIOS GALLEGOS", Tomo XLIII, Fascículo 108, Santiago 1996. 


\section{A declaración previa do Manifesto de Lugo}

O Manifesto de Lugo comenza facendo unha declaración previa, cuasi unha evocación daquela invocación con que comenzaban os documentos solemnes das convencións americanas. Dicía así: «Tendo a Galicia tódal-as características esenciaes de nazonalidade, nós nomeámonos,de oxe pra sempre, nazonalistas galegos, xa que a verba rexionalismo non recolle tódal-as aspiraciós nin encerra toda a intensidade dos nosos problemas». Contra as fórmulas utilizadas do «regionalismo sano y bien entendido», nas que a fala quedaba reducida a un dialecto e a cultura ós seus aspectos máis folklóricos, proclamaban a necesidade de darlle un novo sentido ás palabras, cambiando tal rexionalismo, no seu día perseguido baixo a acusación de separatista, pola de nacionalista. A voz rexionalista volverá a ter carga ideolóxica importante en momentos posteriores da política galega, pero, naquel momento, o avance do nacionalismo clásico, de Irmandades da Fala, acentuaba a nación como suxeito da acción política máis que os seus vencellos cos demais pobos do Estado español. Por outro lado, a apropiación do rexionalismo, polo menos, tal como os irmandiños entendían o concepto de apropiación, polas tendencias centralistas, obrigaba a definir conceptos con novas palabras. En ocasións posteriores, por exemplo, durante a II República, e xa non se diga durante o franquismo, a palabra rexionalismo terá as mesmas connotacións que tiña a voz nacionalista durante a Guerra mundial, polo que a denominación, en realidade, non era «de oxe para sempre», como afirmaban solemnemente os irmandiños.

Do mesmo xeito que había outros máis preocupados pola precisión de palabras como a de autonomía, sobre todo tentando de encanarlle o adxectivo integral, Luís Porteiro, nin teórica nin prácticamente, amosou demasiado interese en darlle a tales palabras o seu sentido máis exacto. Estaba, en cambio, máis interesado en demarca-la liña que debía separalo poder central do poder autonómico por medio da determinación formal das competencias tanto das nacionalidades como do Estado ou goberno central, tentando de reducir este ós contidos mínimos, capaces de permitir un desenvolvemento axeitado dos poderes, da cultura e da personalidade das nacionalidades, concretamente de Galicia. Na carta dirixida a Antón Villar Ponte, ofrecéndose para entrar na Liga de Amigos da Fala, en 1916, fala de «cuestiones de interés nacional o regional», pero tamén de que «Galicia es la única rexión de España que ganaría con una autonomía 
absoluta, integral». No regulamento da Irmandade da Fala de Santiago, en 1916, por exemplo, Porteiro fala de «tendencias rexionalistas», «outras rexiós», «varós rexionalistas», «movementos de carácter rexional».

En A los gallegos emigrados, no capítulo sobre «Una contienda en redor de un vocablo», a pouco da Asemblea de Lugo, Luís Porteiro quixo tranquilizar e convencer ós galegos da Habana sobre o medo a palabras como nacionalista ou rexionalista. Sinalaba Porteiro que cando utilizaban a voz nacionalista se lles acusaba de separatistas, mentres que cando falaban de rexionalismo desaparecía aquela acusación. Lamenta que termos craros no mundo enteiro aínda esixan precisións no seu momento, pero o importantel, segundo pensa, é o contido real da cuestión: «Para nosotros lo importante es reconocer en Galicia un pueblo con propia personalidad; si a tal llegamos, llámese región o nación, este pueblo tendrá características y necesidad de propio gobierno, en los términos de sus caracteres específicos, para atender y respetar éstos». E pregúntase Porteiro: «¿Por qué asustarse de un vocablo tan español que emplearon todos los grandes pensadores españoles —desde Gracián y Cervantes, hasta el historiador La Fuente - los cuales hablaron de las naciones de España y llamaron a Madrid Babilonia de naciones?...».

Porteiro di que ten probado que o vocábulo non debía despertar ningún medo, que só podía ser tal cousa cando se identificaban nación e estado soberano e independente, pero non un mundo no que existen estados-unidos, estados de estados e que «vamos al super-estado y a la sociedad de estados...». Insiste en que é inexplicable tremar ó conxuro de tal palabra, nun momento en que a personalidad do Estado se exalta por uns outorgándolle dereitos subxectivos e se pretende anular outros, en que tódolos Estados poden discutir cuestións semellantes sen medo, cando existen polémicas sobre a personalidade do Estado.

Luís Porteiro tenta de lima-lo significado da palabra: «Nación viene de nascor-nacer. Ha significado el lugar de nacimiento. Hoy vulgarmente se la toma como la unidad política a que pertenece un sujeto en este sentido somos españoles, tanto como el que más, honrándonos con ello. Pero si tomamos la nación como unidad espiritual, somos gallegos y Galicia es nuestra Patria - la unidad espiritual en que nacieron y vivieron nuestros padres - para ella son nuestros amores, y estando ligados por vínculos espirituales y materiales con el resto de los pueblos de España, todo nuestro amor de gallegos a Galicia, es amor a España de la que formamos parte en la prosperidad y en el dolor». 
Interpretando a diferencia entre rexionalismo e nacionalismo establecida no Manifesto de Lugo, Vicente Risco, en 1920, como logo en datas posteriores, tentará de aclaralos motivos dos irmandiños para refugalo rexionalismo e utilizala voz nacionalismo. Di que deixaron a verba rexionalismo porque se apropiaran dela os representantes do «regionalismo sano y bien entendido», pero, xa entrando no fondo das palabras, porque o rexionalismo non pide máis que autonomía administrativa, máis ou menos restricta, só para acadar personalidade na orde da administración, mentres que o nacionalismo quere crear en Galicia unha vida e máis unha cultura autónomas, un aproveitamento de tóda-las forzas de producción material e mental da terra e da raza para a creación de valores económicos e culturais que se poidan impór ó mundo.

\section{Os problemas constituíntes e as mensaxes do Manifesto de Lugo}

Dentro da rúbrica dos problemas constituíntes, o Manifesto recollía a autonomía integral, a autonomía municipal, a cooficialidade idiomática, a federación como fórmula política e o ingreso das nacionalidades da Iberia na Liga das Nacións. Na rúbrica de problemas políticos e na de facultades do poder galego, á súa vez, formulabanse problemas relativos á igualdades da muller, a cuestión electoral, á representación proporcional, acabamento das deputacións provinciais e a creación dun poder autónomo representado por un parlamento galego. As competencias de tal poder galego están descritas no apartado cuarto do manifesto. Non existe, polo tanto, un principio científico de distribución dos contidos, senón unha forma de ordenación de acordo coa trascendencia dos problemas e das cuestións prantexadas.

En 1918 existía a conciencia, formulada expresamente nos textos cataláns, de que era necesaria xa unha autonomía integral. Villar Ponte falaba, calificando o rexionalismo de Brañas e de Cabeza de León, de rexionalismo integral e de soberanía rexional, pero a expresión que acadou máis sona en 1918 foi a de autonomía integral. Xohan Vicente Viqueira, o día 15 de novembro de 1918, nun artigo adicado precisamente a Luís Porteiro, definía como programa inmediato, a autonomía integral para Galicia, sustituíndo as actuais deputacións por un parlamento galego, o que daba xa unha pista importante sobre o alcance da autonomía tal como estaba adxectivada.

"CUADERNOS DE ESTUdIOS GALLEGOS", Tomo XLIII, Fascículo 108, Santiago 1996. 
A adxectivación da autonomía coa palabra integral tiña un sentido histórico específico, pois significaba o refugamento do modelo de mancomunidades, vixente desde o ano 1913 en Cataluña. Que a Mancomunidade catalana era un organismo de vida transitoria, que non satisfacía ás arelas rexionais máis que en certos aspectos - no cultural tivo brillantes realizacións-, nen tampouco aplacaba as sospeitas e os recelos dos centralistas, era sabido por uns e mai-los outros. Desde a propia Mancomunidade provincial, o Consello da Mancomunidade, interpretando a vontade das forzas políticas existentes en Cataluña, así como a intención dos organismos cataláns, sobre todo concellos e deputación, propúxose un modelo de autonomía de data 25 de novembro de 1918.

Foi presentado o día 28, polo Consello da Mancomunidade ó Goberno español, presidido por Manuel García Prieto. Coa forza que lle daba un organismo institucional tan importante, pola presión que fixeron as forzas catalanas, o modelo proposto acadou unha sona moi especial e influíu no estado das ideas organizativas periferistas dos distintos pobos de España. A Asemblea de Parlamentarios foi decisiva para que se formalizase o proxecto.

O modelo entregouse cunha mensaxe dirixida ó Presidente do Consello de Ministros. Decíase nel que o problema de Cataluña era a expresión máis fervente e unánime da vontade de Cataluña, e «no creación artificiosa de literatos y políticos», valoración que parecía dirixirse indirectamente a outros nacionalismos. Refíre-se á historia de Cataluña, ás victorias electorais recentes, á Mancomunidade, ás proposicións aprobadas por ista, nas que «palpita la voluntad catalana». Refírese ás Semanas Municipais organizadas pola Escola de Funcionarios da Administración Local, e na Cuarta concretamente, dise mesmo ano, na que se pidía o recoñecemento da autonomía.

Como documento era unha das primeiras, por non dici-la primeira fórmula que se presentaba articulada na historia contemporánea de Cataluña. Se lle presentara outro a María Cristina, pero nunca coa artellamento que tiña xa iste, como se tivera a intención de que entrase en vigor axiña. Era, en todo caso, un indicador da madurez que fora acadando a idea dos modelos organizativos, dos que soamente os federalistas tiñan o costume de artellar en forma articulada.

"CUADERNOS DE ESTUDIOS GALLEGOS", Tomo XLIII, Fascículo 108, Santiago 1996. 
A Minoría republicana presentou no Congreso dos Deputados, o día 17 de novembro de 1917, unha proposición de lei, despois de afirmar que o recoñecemento da personalidade das rexións non é incompatible coa unidade superior da Nación española, nin o é a constitución de Estados rexionais autónomos e libres para rexela súa vida interior coa unidade do Estado español, dicía no artigo primeiro que «El Congreso concede a la región de Cataluña la autonomía integral». Antonio Maura, o día 11 de decembro de 1918, dicía: «¿Autonomía integral? Que me perdonen los señores que han usado la locución en documentos parlamentarios y excusen mi torpeza; yo no sé desenredar la madeja. Autonomía integral no sé lo que es, porque o integral está en autonomía, o integral es independencia; y ya sabemos que no quiere serlo, acabamos de oírlo de labios del señor Albert, y aunque no lo hubiera dicho, yo no lo dudaba. De modo que para mi esas dos palabras que tienen la virtud de entrecruzar sus detellos en formal que no se ven». O problema estaba nos límites, en como se establecían, en como se organizaban. O 20 de novembro de 1918, Cambó afirmaba que xa en 1916 dixo que dera a fórmula de acadalos límites do Estado alemán quie os tivera menores, cousa que acolliu a Asemblea de parlamentarios.

Na carta póstuma de Porteiro non se dicía nada sobre a autonomía integral. Está, en cambio, na ponencia de Villar Ponte na que dicía que Galicia pode ser prenda é única clave dunha futura grand'Iberia: «Reconecendolle Hespaña unha autonomía integral maor e diferente que dos mais povos, tan fonda que reuna todas as características de verdadeira independenza, capaces dedeixárennos no que nós chamamos estado nascente recoñecendolle».

A determinación das competencias de Galicia, en relación co poder central, está explicada con detalle no Manifesto, nesa parte cuarta, de facultades do poder galego. O Manifesto de Lugo, de 18 de outubro de 1918, iniciou públicamente a adhesion do nacionalismo galego a prol dun modelo federalista da vida española, coa introducción do concepto de autonomía integral para a rexión galega, é, consiguientemente, para as demais rexións integrantes do Estado composto. No Manifesto de Lugo, entre os problemas constituintes, se declara a petición de autonomía integral para Galicia. Ó mesmo tempo, iniciabase a liña da necesidade do Estado composto de tipo federal español, ó mesmo tempo que a necesidade da Federación de Iberia. Ainda que non esté explicitado técnicamente, a 
ponencia presentada por Antón Villar Ponte da luces sobre o siñificado do que debía entenderse por federación e por federación da Iberia. A proposta foi feita por Antón Villar Ponte e publicada logo en A Nosa Terra o día 5 de maio de 1919. Está feita con vistas á relación entre Galicia e Portugal e refíre-se á fala, ó dereito, a educación e a diversas relacións entre ámbolos dous pobos. No que afecta á forma de goberno dicía Villar Ponte: «Inda sendo pra nós acidental aforma de Governo, pensamos que unha República hespañola federal facilitaría o progreso do iberismo. E ista accidentalidade condicionada formulámola eisí: Se Portugal fóse Monarquía e Hespaña República, non sería a xuntanza d’entrambos Estados actuaes, perigosa para as instituzóns portuguesas. Mas socedendo o contrario, a Monarquía maor inlfuiría, quixerso ou non, no derrocamento da República menor. Tamén indica que Portugal e Galicia poderan pactaren un régimen dual como nazóns que reconécense atraguidas por unha unidade superior, filla da común naturaleza, que somente asiu sen receios tería ingreso nunha grand'Iberia».

\section{A Mancomunidade catalana e a súa provisoriedade}

Que a Mancomunidade catalana era un organismo de vida transitoria, que non satisfacía ás arelas rexionais dos cataláns máis que en certos aspectos -no cultural tivo brillantes realizacións-, nen tampouco aplacaba as sospeitas e os recelos dos centralistas, era sabido por uns e mailos outros. Desde a propia Mancomunidade provincial, o Consello da Mancomunidade, interpretando a vontade das forzas políticas existentes en Cataluña, así como a intención dos organismos cataláns, sobre todo concellos e deputación, propúxose un modelo de autonomía de data 25 de novembro de 1918. Foi presentado o día 28, polo Consello da Mancomunidade ó Goberno español, presidido por Manuel García Prieto. Coa forza que lle daba un organismo institucional tan importante, pola presión que fixeron as forzas catalanas, o modelo proposto acadou unha sona moi especial e influíu no estado das ideas organizativas periferistas dos distintos pobos de España.

A estructura do texto está integrada por catro Bases, divididas algunhas en parágrafos, sen articular, aínda que algunhas teñen alíneas para cada uunha das materias. O texto ten a súa importancia para a fixación dos modelos de organización autonómica, dispersos en proclamacións e en fórmulas vagas. $\mathrm{O}$ eco das Bases de Manresa, moi xerais, e sen vocación de artellamento positivo, reflexabanse no seu texto. Tampouco estaban

"CUADERNOS DE ESTUDIOS GALLEGOS", Tomo XLIII, Fascículo 108, Santiago 1996. 
alleas as fórmulas utilizadas pola propia Mancomunidade catalana no seu Estatuto vixente. A Base primeira refíre-se ó territorio de Cataluña, constituído polas catro provincias. Pero, introdúcese a cláusula de agregación territorial doutras provincias, total ou parcialmente, sempre que o formulen cando menos as dúas terceiras partes dos Concellos, que o aprobe o Parlamento rexional de Cataluña e que os territorios non estiveran separados do territorio de Cataluña. As provincias contíguas de Cataluña eran as de Aragón ou do Reino de Valencia, pois non había outras. Referíase exclusivamente a provincias españolas, o que excluía calquera aspiración sobre territorios extranxeiros.

O Goberno Rexional de Cataluña está deseñado, en forma moi xeral, na Base segunda das presentadas en 1918 ó goberno español. Soamente algúns aspectos, xa que soamente na medida en que ó Goberno podía interesarlle a organización interna, de competencia exclusiva de Cataluña. O deseño é moi simple, esbozado soamente nas súas liñas maestras. En calquera caso, parece deducirse, de tan pequena referencia, a instauración dun sistema parlamentario puro, sen nengún tipo de limitacións racionalizadoras. En 1918 aínda non estaban moi presentes as racionalizacións e límites da omnipotencia parlamentaria. Un Parlamento e un Poder executivo, responsable políticamente, formalizaban o modelo de gobernación autonómica. O Parlamento estaba previsto en forma bicameral, como no Estado, o que non estaba na tradición parlamentaria de Cataluña, xa que as Cortes catalanas eran unicamerais. A composición do Parlamento era por sufraxio universal e directo nunha das Cámaras. Non había outras aclaracións sobre a organización e funcionamento, por ser cousas que estimaban, de seguro, como de organización interna. A segunda Cámara estaba composta por representantes de segundo grao, elexidos polo voto dos concelleiros de tódo-los concellos de Cataluña. Nada se dicía sobre o número de escanos.

Na segunda das Bases dise que o Goberno Rexional terá plena soberanía para rexe-los asuntos interiores de Cataluña. O uso da palabra soberanía, como soberanía interior, levantaba a sospeita de moitos centralistas, que preferían o uso da palabra autonomía, como entidade conceptual subordinada. A expresión «asuntos interiores» estaba definida por exclusión na mesma Base. Era asunto interior todo o que non estaba reservado expresamente ó Estado. As relacións internacionais, a Defensa, a nacionalidade e o exercicio dos dereitos individuais, o réxime arancela- 
rio, comercio e alfandegas; a lexislación penal e mercantil, pesas, medidas e moeda, eficacia dos documentos, como competencias exclusivas do Estado. Sen embargo, xa como competencias compartidas, implícitamente, figuraban aspectos definidos polo interese xeral, como os ferrocarrís, ou a reglamentación dos servizos de correos e telégrafos, o que podía indica-la competencia execución reservada ó Estado. Aplicado por Luís Peña Novo ó caso galego, non chegará a desenvolverse un sistema nin unha base organizativa para a súa incoporación á realidade, por non ter incidencia sobre un modelo de organización política de Galicia. Pero, aquela experiencia que non pasaba da simple formulación do modelo será un paso significativo na concreción das experiencias alleas que a autonomía galega debía examinar co fin de chegar a unha máis axeitada institucionalización política da realidade galega.

O modelo da mancomunidade galega non chegou a callar nos anos seguintes, e, moito menos, por suposto, calquera outra forma de organización administratativa do territorio galego que tivera algún acento distinto ó do réxime provincial establecido. Sen embargo, o Real Decreto de 12 de xaneiro de 1924 parecía abrir un novo portelo á esperanza dun modelo mancomunalista semellante ó existente en Cataluña. O seu artigo primeiro dispoñía a disolución das deputacións provinciais, encargando ós gobernadores civís a designación de novos deputados provinciais con carácter interino. Así mesmo, ademais de esixir ás novas corporacións o envío dunha Memoria na que constasen as anomalías detectadas, se lles facultaba para solicitar ou propoñela constitución de Mancomunidades provinciais, dacordo co previsto no Real Decreto do 18 de novembro de 1913. Ámbalas medidas, anunciadas xa desde o primeiro momento do Golpe militar, tivera certo eco favorable entre descentralizados e nacionalistas conservadores. Os titulares de El Noroeste, do 23 de setembro de 1923, son moi expresivos das esperanzas postas na erradicación do caciquismo provincial e local en Galicia: «Para vertebrar a España/ Galicia entera reclama unánime el estatuto regional/ Urge un decreto de supresión de las Diputaciones provinciales/ Las bases de la reforma de la administración local/ El descuaje del caciquismo/ ¿Asesora al Directorio la Mancomunidad catalana?/ El Directorio sigue destruyendo enchufes y suprimiendo momios, etc». A Nosa Terra, en cambio, o día 1 de febreiro de 1924, precisaba que «non foron disoltas as Diputacións. Foron botadas delas os que as viñan ocupando e facendo dende aquel posto o caci-

"CUADERNOS DE ESTUdIOS GALLEGOS", Tomo XLIII, Fascículo 108, Santiago 1996. 
quismo noxento que sempre combatimos. Máis non creemos nós que eso todo quedou resolto». Neste ambiente de desconfianza duns e de euforia doutros, o día 20 de xaneiro de 1924 constituíronse as novas deputacións provinciais. O día 26 de marzo de 1924 celebrouse una nova Asemblea de representantes das catro deputacións provinciais de Galicia, na que se volvía a demora-la creación do modelo mancomunalista galego. Falaremos desto con máis vagar noutro momento, porque o asunto require algún tramento específico para fixa-los avatares polos que pasou o modelo mancomunalista en Galicia e fora de Galicia.

\section{BIBLIOGRAFÍA MÍNIMA}

Xosé CALVO SOTELO: Mis servicios al Estado. Seis años de gestión. Imprenta Clásica Española. Madrid, 1931. Axuicia a obra da Mancomunid de catalana nestes termos: "La administrativa, no fue tan irregular como se dijo; la cultural fue francamente estimuladora. Lo grave de una y otra era su matiz particularista, intransigente”.

J. CHARLES-BRUN: El regionalismo. Traducción, introducción, notas y apéndices de José García Acuña. Francisco Beltrán. Madrid, 1918.

Baldomero CORES TRASMONTE: En El Correo Gallego, «As Mancomunidades provinciais e instalación rexional da provincia», (7 de xullo de 1991); «A ciencia xurídica e as mancomunidades provinciais», (287-91); «As Mancomunidades provinciais, empeño persoal de Canalejas», (14-7-91); «Montero Ríos e o til dos seus ideais xacobinos», (21-7-91).

Sociología política de Galicia. Orígenes y desarrollo (1846-1936). Librigal, Coruña, 1976. (Por primeira vez se desenvolve o fío conductor entre provincialismo, federalismo, rexionalismo, mancomunalismo, que alí se chama mancomunidalismo e autonomismo, que serviu de base para unha articulación do pensamento político galego desde unha perspectiva común).

La devolución de Galicia. El Estatuto: ayer y hoy. Libros Minerva. Santiago, 1977.

"CUADERNOS DE ESTUDIOS GALLEGOS", Tomo XLIII, Fascículo 108, Santiago 1996. 
A Constitución de Cuba e Porto Rico, primeiro modelo autonómico español. «Estudios de Historia Social», $\mathrm{n}^{\text {os }}$ 28-29, Madrid, 1984, pp. 407-415.

Las polémicas de Bóveda en la gestación del Estatuto de Autonomía. Ediciós do Castro. Sada, 1986.

Ciencia e galeguidade na II República. Xunta de Galicia. Santiago, 1989. (Describe-se con moito detalle o proceso estatutario de 1936). Estructura política de Galicia. Santiago, 1994. (Analíza-se a repartición competencial dos textos galegos de Galicia desde unha perspectiva histórica).

Galicia e a división do territorio español. «Pontevedra». Revista de Estudios Provinciais. Número 11, 1995, pp. 169-188.

DIARIO DE LAS SESIONES DE CORTES, tanto do Congreso dos Deputados como do Senado, referentes ó ano 1912.

XOSÉ GARCÍA ACUÑA: Idearium regionalista. Ediciones de «El Noroeste». A Coruña, 1926.

XOSÉ GASCÓN Y MARÍN: Mancomunidades provinciales. Hijos de Reus, editores. Madrid, 1914.

PABLO GONZÁLEZ MARIÑAS: A Administración galega na súa perspectiva histórica: Cuestións e problemas de organización territorial e administrativa. I Simposio da historia da Administración pública. Escola de Administración Pública. Santiago, 1993; La Mancomunidad gallega. «Estudios de Historia Social». Madrid, 1984, $\mathrm{n}^{\text {os }} 28-29$, pp. 359-361.

ADOLFO GONZÁLEZ POSADA: Evolución legislativa del régimen local español. Madrid, 1912.

LLIGA REGIONALISTA DE BARCELONA: Las Mancomunidades. Barcelona, 1912.

SEBASTIÁN MARTÍN-RETORTILLO, Luís COSCULLUELA e Enrique ORDUÑA: Autonomías regionales en España. Instituto de Estudios de Administración Local. Madrid, 1978.

"CUADERNOS DE ESTUDIOS GALLEGOS", Tomo XLIII, Fascículo 108, Santiago 1996. 
LUÍS PEÑA NOVO: La Mancomunidad Gallega. Imprenta M. Roel. Vigo, 1921.

MANUEL ROCA CENDÁN: Lois Peña Novo. Vida e pensamento político e económico. Ediciós do Castro. Sada, 1992.

\section{PESQUISA HEMEROGRÁFICA}

A Nosa Terra, El Ideal Gallego, La Voz de Galicia, Faro de Vigo, El Compostelano, Galicia, $A B C$, entre outros. 